\title{
Sizing and Dynamic Modeling of a Power System for the MUN Explorer Autonomous Underwater Vehicle Using a Fuel Cell and Batteries
}

\author{
Mohamed M. Albarghot $\mathbb{D}^{1},{ }^{1}$ M. Tariq Iqbal $\mathbb{D}^{,},{ }^{2}$ Kevin Pope, ${ }^{1}$ and Luc Rolland ${ }^{3}$ \\ ${ }^{1}$ Department of Mechanical Engineering, Memorial University of Newfoundland, St. John's, NL, Canada \\ ${ }^{2}$ Department of Electrical Engineering, Memorial University of Newfoundland, St. John's, NL, Canada \\ ${ }^{3}$ Department of Automation and Controls, University of West Scotland, Scotland, UK \\ Correspondence should be addressed to Mohamed M. Albarghot; mma216@mun.ca
}

Received 5 January 2019; Accepted 27 February 2019; Published 16 April 2019

Academic Editor: Johan E. Hustad

Copyright (C) 2019 Mohamed M. Albarghot et al. This is an open access article distributed under the Creative Commons Attribution License, which permits unrestricted use, distribution, and reproduction in any medium, provided the original work is properly cited.

The combination of a fuel cell and batteries has promising potential for powering autonomous vehicles. The MUN Explorer Autonomous Underwater Vehicle (AUV) is built to do mapping-type missions of seabeds as well as survey missions. These missions require a great deal of power to reach underwater depths (i.e., 3000 meters). The MUN Explorer uses 11 rechargeable Lithiumion (Li-ion) batteries as the main power source with a total capacity of $14.6 \mathrm{kWh}$ to $17.952 \mathrm{kWh}$, and the vehicle can run for 10 hours. The drawbacks of operating the existing power system of the MUN Explorer, which was done by the researcher at the Holyrood management facility, include mobilization costs, logistics and transport, and facility access, all of which should be taken into consideration. Recharging the batteries for at least 8 hours is also very challenging and time consuming. To overcome these challenges and run the MUN Explorer for a long time, it is essential to integrate a fuel cell into an existing power system (i.e., battery bank). The integration of the fuel cell not only will increase the system power, but will also reduce the number of batteries needed as suggested by HOMER software. In this paper, an integrated fuel cell is designed to be added into the MUN Explorer AUV along with a battery bank system to increase its power system. The system sizing is performed using HOMER software. The results from HOMER software show that a 1-kW fuel cell and $8 \mathrm{Li}$-ion batteries can increase the power system capacity to $68 \mathrm{kWh}$. The dynamic model is then built in MATLAB/Simulink environment to provide a better understanding of the system behavior. The 1-kW fuel cell is connected to a DC/DC Boost Converter to increase the output voltage from $24 \mathrm{~V}$ to $48 \mathrm{~V}$ as required by the battery and DC motor. A hydrogen gas tank is also included in the model. The advantage of installing the hydrogen and oxygen tanks beside the batteries is that it helps the buoyancy force in underwater depths. The design of this system is based on MUN Explorer data sheets and system dynamic simulation results.

\section{Introduction}

The MUN Explorer AUV is an autonomous underwater vehicle used for missions such as mapping, surveillance, oceanographic data gathering, environmental monitoring, mine detecting, and coastal defence [1]. One of the challenges facing the MUN Explorer is the power system's capacity to complete its missions. To improve the system's energy capacity, the MUN Explorer AUV is taken as a real example to do sizing and to build a dynamic model. The MUN AUV has a length of $5.3 \mathrm{~m}$, a diameter of $0.69 \mathrm{~m}$, and a dry weight of 820 $\mathrm{kg}$. In water, the flooded front and back sections of the AUV make the mass around $1400 \mathrm{Kg}$, with an average speed of 1.5 $\mathrm{m} / \mathrm{s}$, graphing over $80 \mathrm{Km}$. Some components have also been integrated into the vehicle such as computers and sensors.

Hydrogen production by Proton Exchange Membrane (PEM) water electrolysis is a promising method that has been successfully developed and integrated into renewable and hydrogen energy-based systems. Renewable energy sources, such as solar and wind, are desirable for hydrogen production due to random variations and significant current density capabilities [2]. PEM water electrolysis technology that generates hydrogen primarily emits water moisture, nitrogen, and oxygen [3]. Energy storage or backup power systems are 
needed for photovoltaic and wind energy systems due to their discontinuous energy production. Batteries can be a good solution for daily storage but not for seasonal storage due to self-discharge. Storing energy in the form of hydrogen gas that is generated from renewable sources is a possible solution for both daily and seasonal storage [4]. For example, Sopian et al. (2009) integrated a photovoltaic-wind-hydrogen energy production/storage system. The components of the system were a photovoltaic array, wind turbine, PEM electrolyzer, battery bank, and hydrogen tank. The system also had an automatic control system for battery charging and discharging. A hydrogen quantity of $130 \mathrm{ml} / \mathrm{min}$ to $140 \mathrm{ml} / \mathrm{min}$ was generated for an average global solar radiation between 200 $\mathrm{W} / \mathrm{m}^{2}$ and $800 \mathrm{~W} / \mathrm{m}^{2}$ and wind velocities ranging from 2.0 $\mathrm{m} / \mathrm{s}$ to $5.0 \mathrm{~m} / \mathrm{s}$. For each system component, a mathematical model was built and compared to the experimental results [5]. Lithium-ion (Li-ion) battery technology has improved in the past decade. Li-ion batteries have higher energy and power density, higher efficiency, and lower self-discharge when compared to other batteries $(\mathrm{NiCd}, \mathrm{NiMH}$, and Lead Acid). To ensure the Li-ion battery is operating at a proper temperature and state of charge (SOC), a battery management supervision system (BMSS) must be applied [6]. Fuel cells' high energy density, quiet operation, and high efficiency have allowed them to be used as a portable energy source. The capacity of fuel cells increased worldwide from $65 \mathrm{MW}$ in 2009 to $181 \mathrm{MW}$ in 2014 [7, 8]. Many types of fuel cells such as the proton exchange membrane fuel cell, alkaline fuel cell, and phosphoric acid fuel cell use hydrogen as fuel to produce electricity and water. Hydrogen-specific energy is high compared to other fuels' specific energy. Fuel cells have many applications such as stationary, transportation, and portable applications. Proton exchange membrane fuel cells have a higher efficiency compared to phosphoric acid fuel cells and alkaline fuel cells [9].

Using compressed hydrogen in composite cylinders for fuel cells is an alternative for underwater vehicles. Composite cylinders have a low weight and can increase the total performance of a deep-diving AUV. Furthermore, hydrogen cylinders may help buoyancy compensation in underwater depths. The design for underwater depths makes the weight of the pressure hull increase, and as a result, the amount of energy carried in a vehicle with neutral buoyancy is minimized with the design depth. Considering this, the batteries inside the vehicle should be as light as possible [10]. AUV energy supply powered by a fuel cell has been integrated on an IFREMER survey AUV called IDEFX by HELION, an AREVA Renewable subsidiary. Several experiments have demonstrated the interest in underwater power sources by installing a fuel cell along with a hydrogen gas tank [11].

This paper aims to design, size, and integrate a fuel cell into an existing power system that uses a battery bank as the main energy source to power the MUN Explorer AUV. By adding a fuel cell into the MUN Explorer, the power system capacity will be increased. However, the weight and the number of batteries can be reduced accordingly, and the number of hours of operation will increase. In this work, the focus will be on the main four components: the oxygen and hydrogen tanks, PEM fuel cell, Li-ion battery, and DC

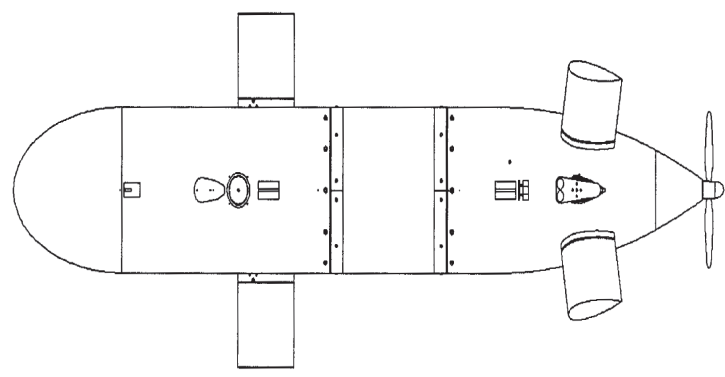

FIgURE 1: Hull structure of the MUN Explorer AUV.

motor (load). This paper is divided into three sections: the first section illustrates the components and system sizing using Hybrid Optimization Model for Electrical Renewable (HOMER) software; the second section demonstrates the dynamic modeling, simulation, and results; and the third section is the conclusion.

\section{Components and System Sizing}

\subsection{Hydrogen/Oxygen Tanks and PEM Fuel Cell. The MUN} Explorer Autonomous Underwater Vehicle as shown in Figure 1 has plenty of vacant space that could be used to install the hydrogen and oxygen tanks as well as the fuel cell.

The hydrogen consumed by the proton exchange membrane fuel cell (PEMFC) can be generated directly from the electrolyzer. The hydrogen gas also depends on the relationship between the output power and the hydrogen needed for the PEMFC system. Excess hydrogen is directed to the storage tank. Due to the lack of an oxygen gas underwater surface, the fuel cell operation in underwater vehicles requires oxygen gas storage to complete the reaction between the cathode and the anode. By carrying the oxygen into the AUV, the fuel cell performance is increased by 2 to 3 times. To remove the produced water from the fuel cell during the operation, extra oxygen must be brought into the vehicle. This should be measured when the sizing of the oxygen storage is completed [16]. There are many ways to store hydrogen and oxygen. For example, compressed gas or liquid hydrogen and oxygen can be applied. HOMER software is designed to deal with renewable/nonrenewable energy components and integrate them with each other. HOMER works by providing inputs (i.e., capital cost and size to consider $\mathrm{kW}$ ) and design information about any given power system. HOMER simulation will give the system configurations and then create a list of feasible system designs and sort that list according to cost-effectiveness. Finally, a sensitivity analysis can be performed. The complete HOMER block diagram is illustrated in Figure 2.

This diagram consists of renewable energy sources such as solar and wind to generate electricity to power the electrolyzer and then charge the battery. After that, the electrolyzer will generate the hydrogen and oxygen gases. Finally, the fuel cell and the battery will power the DC motor. It is understood that the wind energy, solar energy, and electrolyzer will be onshore, and hydrogen and oxygen will 


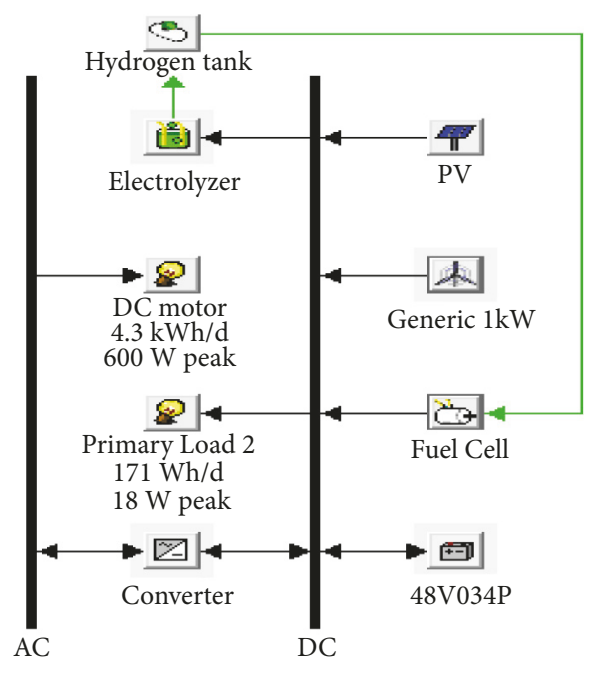

FIGURE 2: HOMER block diagram.

be transferred to the AUV when it is docked. To run the HOMER software, the capital cost (i.e., commercial prices) of three different hydrogen tanks along with the sizes to consider ( $\mathrm{kg}$ or $\mathrm{kW}$ ) need to be entered into the hydrogen tank inputs. However, the reason for selecting three or more different hydrogen tanks is to give HOMER software more options to choose from so it can select the most optimal results. The same procedure is done for the fuel cell inputs, electrolyzer inputs, battery inputs, convertor inputs, PV inputs, and wind turbine inputs. The data sheet of each input and its price can be found in the attached Appendix. Figure 3 shows the simulation result of HOMER software in terms of the hydrogen tank storage level in $\mathrm{kg}$ and monthly statistics as well as frequency histogram. Since HOMER software does not have an oxygen tank input, the sizing will only be performed analytically in the next sections. After the capital cost and sizes to consider $(0.2 \mathrm{~kW}, 0.3 \mathrm{~kW}$, and $0.5 \mathrm{~kW})$ have been set for the fuel cell inputs, the simulation runs to give the results as shown in Figure 4. The values in the gray line have been chosen from HOMER software. The FC results are shown in Figure 5.

2.2. Lithium-Ion Battery and Converter. The MUN Explorer uses Li-ion batteries as its main source of energy to power loads, which include all electronics onboard and the emergency lights. That is because these batteries have high energy density and efficiency compared to other types of batteries. A Li-ion battery is more attractive in portable applications such as automotive and autonomous vehicles.

The cost of the Li-ion batteries and size to consider (i.e., number of batteries) have been entered into HOMER software inputs. Figure 6 shows the battery characteristic results. The battery has a nominal voltage of $48 \mathrm{~V}$ and nominal capacity of $34 \mathrm{Ah}$. The DC bus of the system is set to be $48 \mathrm{~V}$, which means the battery also must be $48 \mathrm{~V}$. Those characteristics were provided by the battery's data sheet as well. The DC/DC boost converter is well known as a stepup converter, which takes a lower voltage to a higher voltage. The HOMER results suggested that a $2 \mathrm{~kW}$ DC/DC converter should be used in the system. The efficiency of a DC/DC converter is always above $90 \%$, and it has a lifetime up to 15 years.

2.3. Permanent Magnetic DC Motor (PMDC). In this case, the PMDC motor represents the load in HOMER software, and it is powered by the fuel cell and the battery. Permanent magnetic direct current (PMDC) motors are electrical machines that convert direct current electrical energy into mechanical energy. They are commonly used in many industrial, residential, and commercial applications [18]. The MUN Explorer AUV runs for ten (10) hours, so that the load has been specified based on the hours of operations (i.e., 10 hours) to be $600 \mathrm{~W}$ as illustrated in Figure 7. The load is also divided into two sections: a DC load, which represents the electronics onboard, and the AC load, which is a variable speed motor. The MUN Explorer has only DC components, so the reason for selecting AC in HOMER is to represent the motor drive in our sizing.

\section{System Dynamic Model}

3.1. Hydrogen/Oxygen Tank and PEM Fuel Cell. The storage system in the MUN Explorer could be challenging to install. As mentioned above, there are many ways to store compressed or liquid hydrogen and oxygen, especially for the MUN Explorer applications. Compressed or liquid hydrogen and oxygen storage gases can be implemented in terms of specific energies and energy densities. Effective storage systems that have higher energy density (ED) and specific energy (SE) are preferred [16].

The advantages of compressed hydrogen do not need preprocessing and are the easiest and cheapest solution for dealing with fuel storage. However, to maximize hydrogen content, high pressures (up to 700 bar) can be applied due to the low energy density of hydrogen gas. Liquid hydrogen has a higher density than gas. Liquid hydrogen also needs a temperature that is less than $20.15 \mathrm{~K}$, so the stored liquid hydrogen must be in cryogenic Dewars (multi-shell flasks using an evacuated interstitial space) to eliminate heat transfer throughout the flask and prevent gas from reaching the boiling stage. Table 1 shows the specific energy and the energy density for compressed and liquid hydrogen storage systems, respectively [16].

Lightweight tanks for transporting the compressed oxygen applications are more accessible than the hydrogen ones because hydrogen tanks are used in automotive vehicle applications, while oxygen tanks are often used in medical applications. In short, hydrogen tanks can be modified for oxygen storage systems [17]. "Since high-pressure oxygen has a simple delivery mechanism, the desired oxygen tank wall thickness increases with pressure, which causes a reduction in the energy density advantages" [19]. Liquid oxygen storage can be a suitable solution for limited space applications. Some drawbacks of this storage system are its complexity due to the 


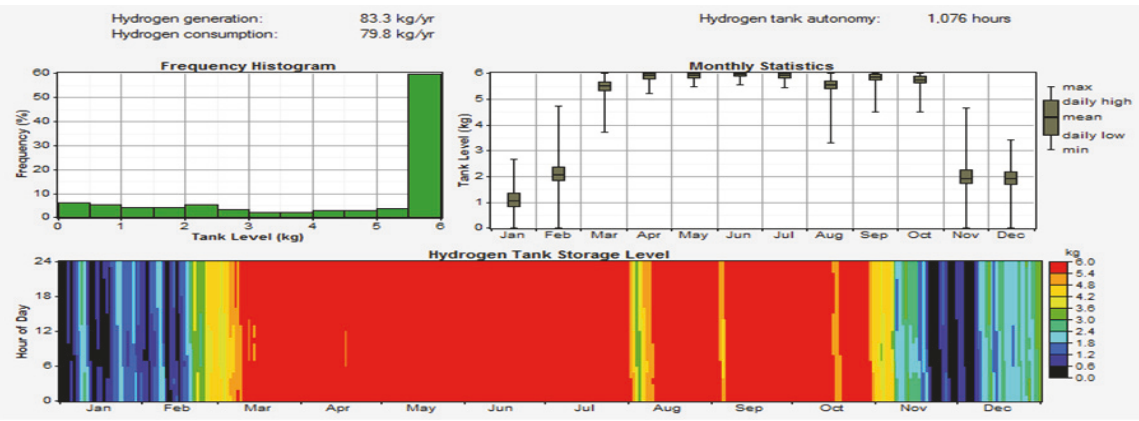

FIGURE 3: Simulation results from HOMER software for the hydrogen tank.

\begin{tabular}{|c|c|c|c|c|c|c|c|c|c|c|c|}
\hline 办的回 & $\begin{array}{c}\text { PV } \\
(\mathrm{kW})\end{array}$ & G1 & $\begin{array}{c}\mathrm{FC} \\
(\mathrm{kW})\end{array}$ & $48 \mathrm{~V} 034 \mathrm{P}$ & $\begin{array}{l}\text { Conv. } \\
(\mathrm{kW})\end{array}$ & $\begin{array}{l}\text { Elec. } \\
(\mathrm{kW})\end{array}$ & \begin{tabular}{|c|}
$\begin{array}{c}\text { H2 Tank } \\
(\mathrm{kg})\end{array}$ \\
\end{tabular} & $\begin{array}{l}\text { Intial } \\
\text { Capital }\end{array}$ & $\begin{array}{l}\text { Operating } \\
\text { Cost (S/yr) }\end{array}$ & $\begin{array}{l}\text { Total } \\
\text { NPC }\end{array}$ & $\begin{array}{c}\mathrm{COE} \\
(\mathrm{S} / \mathrm{kWh})\end{array}$ \\
\hline & 7.02 & 1 & 1.0 & 10 & 2.0 & 2.4 & 6.000 & \$ 109.276 & 760 & \$ 118.997 & 5.717 \\
\hline & 5.46 & 1 & 0.5 & 11 & 1.5 & 1.2 & 7.000 & $\$ 96.130$ & 1.792 & $\$ 119.036$ & 5.721 \\
\hline & 7.02 & 1 & 0.5 & 11 & 2.5 & 1.2 & 6.000 & \$ 98.769 & 1.589 & \$ 119.079 & 5.721 \\
\hline & 6.24 & 1 & 0.5 & 8 & 2.5 & 2.4 & 6.000 & \$ 101.409 & 1.385 & \$ 119.113 & 5.726 \\
\hline & 7.80 & 1 & 0.5 & 9 & 1.5 & 1.2 & 6.000 & $\$ 100.089$ & 1.490 & \$ 119.140 & 5.725 \\
\hline & 7.80 & 1 & 1.0 & 8 & 2.0 & 2.4 & 6.000 & $\$ 111.196$ & 626 & $\$ 119.199$ & 5.729 \\
\hline & 5.46 & 1 & 0.5 & 11 & 1.0 & 2.4 & 6.000 & \$ 99.429 & 1.548 & \$ 119.217 & 5.728 \\
\hline & 6.24 & 1 & 0.5 & 9 & 1.5 & 2.4 & 6.000 & \$ 101.649 & 1.381 & \$ 119.297 & 5.733 \\
\hline & 7.02 & 1 & 1.0 & 11 & 1.5 & 2.4 & 6.000 & \$ 109.816 & 744 & \$ 119.327 & 5.733 \\
\hline & 7.02 & 1 & 1.0 & 10 & 2.5 & 2.4 & 6.000 & \$ 109.576 & 763 & \$ 119.331 & 5.733 \\
\hline & 5.46 & 1 & 0.5 & 11 & 2.0 & 1.2 & 7.000 & $\$ 96.430$ & 1.795 & \$ 119.370 & 5.737 \\
\hline 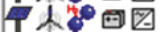 & 7.02 & 1 & 0.5 & 11 & 3.0 & 1.2 & 6.000 & \$ 99.069 & 1.591 & \$ 119.413 & 5.737 \\
\hline
\end{tabular}

Figure 4: Suggested results simulation by HOMER software.

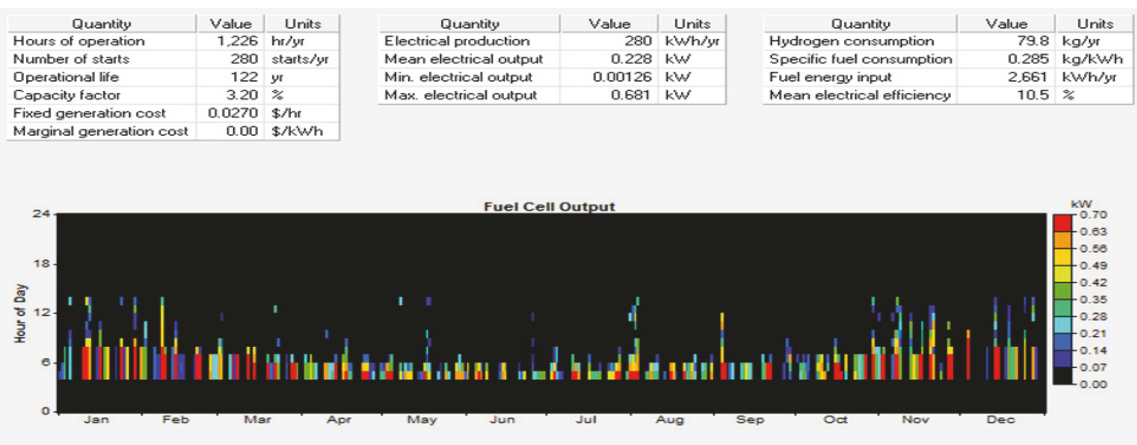

FIGURE 5: HOMER software results for the fuel cell inputs.

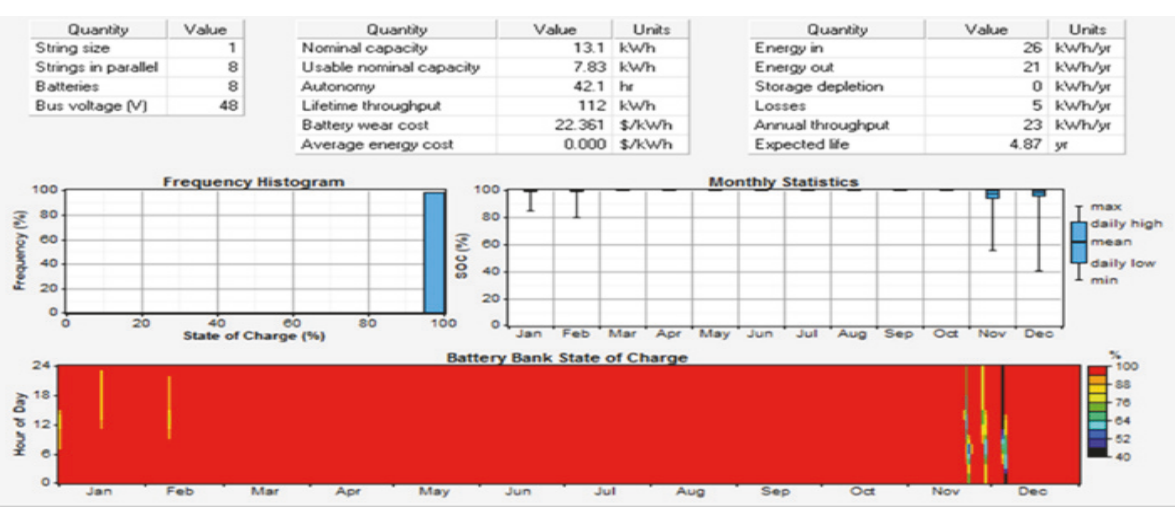

FIGURE 6: HOMER software results for the battery. 


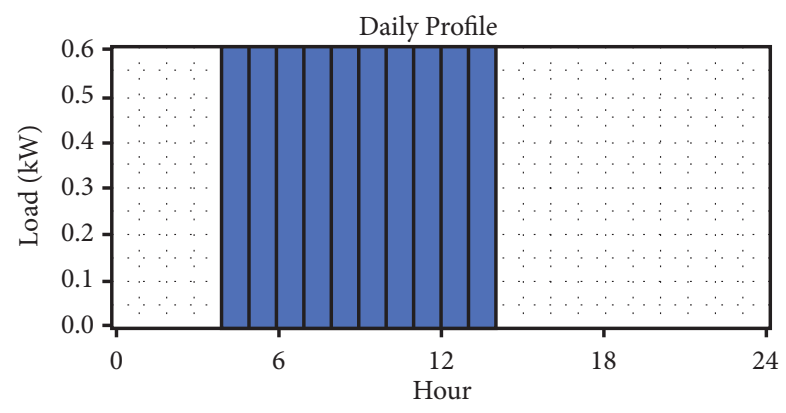

Figure 7: The load for the DC motor in HOMER.

TABLE 1: Hydrogen storage system for SE and ED.

\begin{tabular}{lcc}
\hline Hydrogen & Specific Energy $(\mathrm{kWh} / \mathrm{kg})$ & Energy Density $(\mathrm{kW} / \mathrm{L})$ \\
\hline Compressed & $1.71-1.82$ & $0.56-0.82$ \\
Liquid & 2.05 & 1.86 \\
\hline
\end{tabular}

TABLE 2: Oxygen storage system for SE and ED.

\begin{tabular}{lcc}
\hline Oxygen & Specific Energy $(\mathrm{kWh} / \mathrm{kg})$ & Energy Density $(\mathrm{kW} / \mathrm{L})$ \\
\hline Compressed & $0.77-1.68$ & $0.6-1.09$ \\
Liquid & $2.9-3.3$ & $2.78-2.98$ \\
\hline
\end{tabular}

safety concerns associated with the handling and refueling process [19]. A liquid oxygen storage system prototype has been designed by Sierra Lobo, Inc. with a diameter of 54 $\mathrm{cm}$ (21 inches) [17]. This prototype can store $50 \mathrm{~kg}$ of liquid oxygen at $452 \mathrm{k}$ to run a 1-kW output PEM fuel cell. The system is $0.94-\mathrm{m}$ long and $0.32 \mathrm{~m}$ in diameter. The weight is $13.6 \mathrm{~kg}$ when it is empty and $63.6 \mathrm{~kg}$ when it is full [20]. Table 2 shows the specific energy and the energy density for compressed and liquid oxygen storage systems, respectively [17].

In this paper, the model for the compressed oxygen/hydrogen tank corresponds to the one used by $[12,13]$. The dynamic model of oxygen/hydrogen tank was built based on (1) and (2) in the MATLAB/Simulink environment as shown in Figures 8 and 9. The compressibility factor is defined as a function of temperature and pressure. Its value equals 1 when the pressure is less than $2000 \mathrm{psi}$ and is higher than 1 when the pressure is higher than 2000 psi at room temperature [13].

$$
\begin{aligned}
P_{b}-P_{b i} & =z * \frac{N_{H 2} R T_{b}}{M_{H 2} V_{b}} \\
Z & =\frac{P V_{m}}{R T}
\end{aligned}
$$

To evaluate the fuel cell in terms of specific energy and energy density, a commercial fuel cell (Horizon 100W PEM Fuel Cell) is integrated into the storage systems. It is selected due to the effectiveness of Horizon fuel cells and its recognised experience in AUV fuel cell applications. Table 3 shows the fuel cell parameters.
The calculation of the ED and SE of the complete storage system is represented as follows [16]:

$$
\begin{gathered}
E D_{s s}=\frac{E D_{H 2} * E D_{\mathrm{O} 2}}{E D_{H 2}+E D_{\mathrm{O} 2}} \\
S E_{s s}=\frac{S E_{H 2} * S E_{\mathrm{O} 2}}{S E_{H 2}+S E_{\mathrm{O} 2}}
\end{gathered}
$$

Those equations were applied for reactant storage combinations of liquid hydrogen/liquid oxygen and compressed hydrogen/compressed oxygen.

A polymer electrolyte membrane is an important component of a PEM fuel cell that is connected between the electrodes (anode and cathode). The cathode must be supplied by oxygen gas, whereas the anode must be supplied with hydrogen. The overall electrochemical dynamic can be represented by the following equations [14]:

$$
\begin{aligned}
& \text { Cathode: } \mathrm{O}_{2}+4 \mathrm{H}^{+}+4 e^{-} \longleftrightarrow 2 \mathrm{H}_{2} \mathrm{O} \\
& \text { Anode: } 2 \mathrm{H}_{2} \longleftrightarrow 4 \mathrm{H}^{+}+4 e^{-} \\
& \text {Overall: } 2 \mathrm{H}_{2}+\mathrm{O}_{2} \longleftrightarrow 2 \mathrm{H}_{2} \mathrm{O}+\text { electricity + heat }
\end{aligned}
$$

For any fuel cell, both the anode and cathode can be represented by the mole conservation equations as follows [14]:

$$
\begin{aligned}
& \frac{d P_{H 2}}{d t}=\frac{R T}{V_{a}}\left[H_{2 \text { in }}-H_{2 \text { used }}-H_{2 o u t}\right] \\
& \frac{d P_{\mathrm{O} 2}}{d t}=\frac{R T}{V_{c}}\left[O_{2 \text { in }}-O_{2 \text { used }}-O_{2 o u t}\right]
\end{aligned}
$$

The fuel cell dynamic is built in a model in Simulink using a controlled voltage source in series with a constant resistance as illustrated in Figure 10 [21].

Equation (10) describes the controlled voltage source (E), so that

$$
\begin{aligned}
E & =E_{o c}-N A \ln \left(\frac{i_{f c}}{i_{0}}\right) * \frac{1}{s T_{d} / 3+1} \\
V_{f c} & =E-R_{o h m} * i_{f c}
\end{aligned}
$$

Equation (10) shows the fuel cell stack voltage as function of activation losses because of the slowness of chemical reactions at the electrode surfaces [21]. A parallel RC branch is used to model the losses electrically. Thus, for the rapid changes in the fuel cell current, the stack voltage will demonstrate a delay response that can be 3 times to the time constant $(\tau=R C)$ prior to equilibrium. Equation (10) also illustrates a phenomenon which delays the activation losses with a first-order transfer function $\left(1 /\left(s T_{d} / 3+1\right)\right)$, where $\mathrm{T}_{\mathrm{d}}$ is the stack settling time. Equation (11) represents the total fuel cell voltage by taking the losses into account due to electrodes and electrolyte resistances (ohmic losses). This model is a simplified model that can simulate a fuel cell stack at a nominal condition of pressure and temperature operations. To eliminate the flow of negative current into 
TABLE 3: Fuel cell parameters.

\begin{tabular}{lcccc}
\hline Weight $(\mathrm{kg})$ & Dimensions $(\mathrm{cm})$ & Volume $(\mathrm{L})$ & Specific Power $(\mathrm{W} / \mathrm{kg})$ & Power Density $(\mathrm{W} / \mathrm{L})$ \\
\hline 4 & $23.3 * 26.8 * 12.3$ & 7.68 & 250 & 130 \\
\hline
\end{tabular}

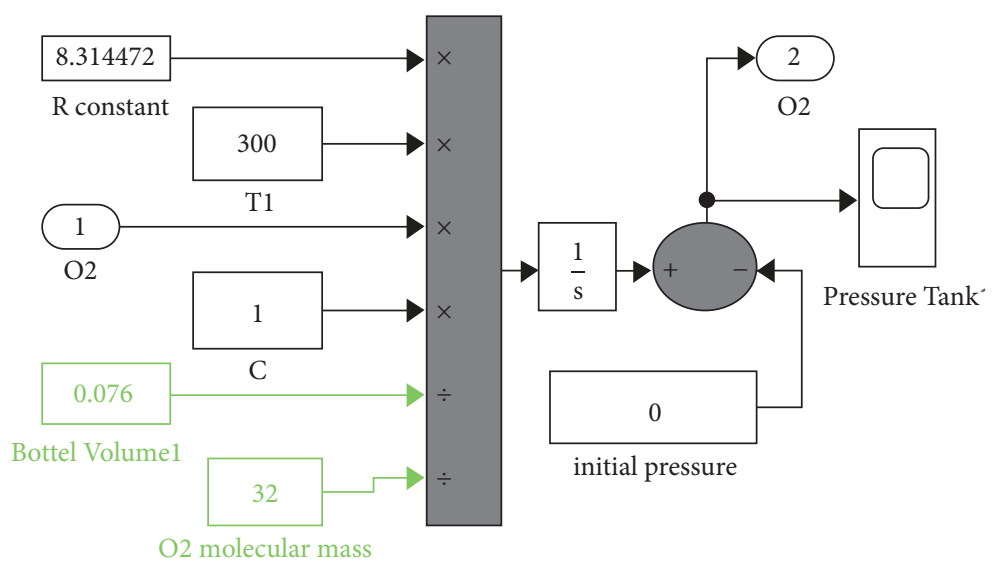

FIgURE 8: Oxygen tank in MATLAB/Simulink $[12,13]$.

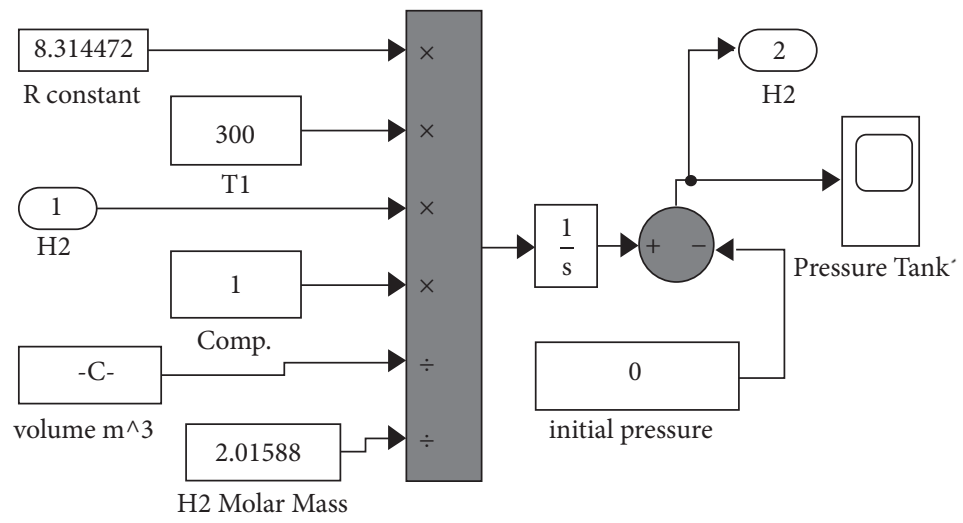

FIgURE 9: Hydrogen tank in MATLAB/Simulink [12, 13].

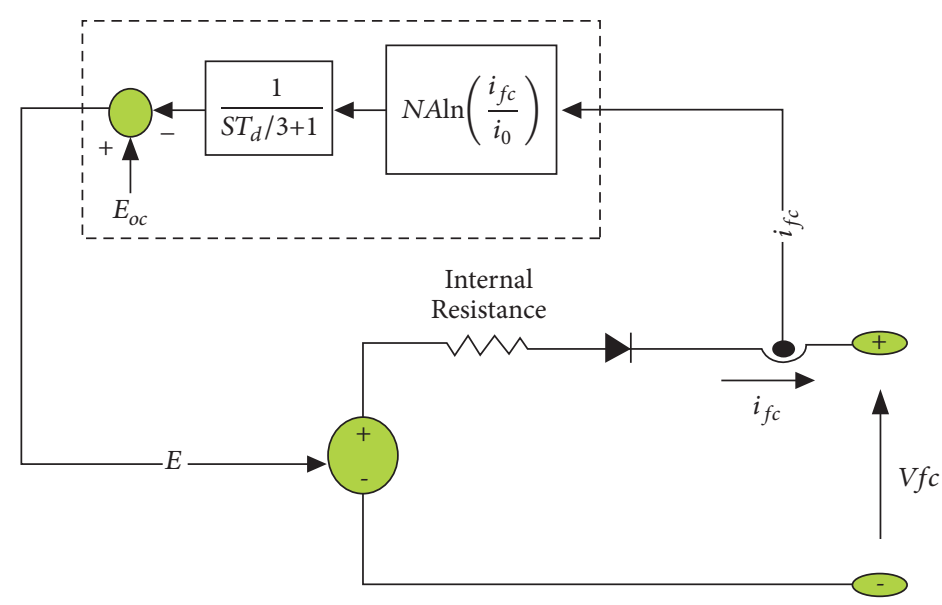

FIGURE 10: Fuel cell stack model [14]. 

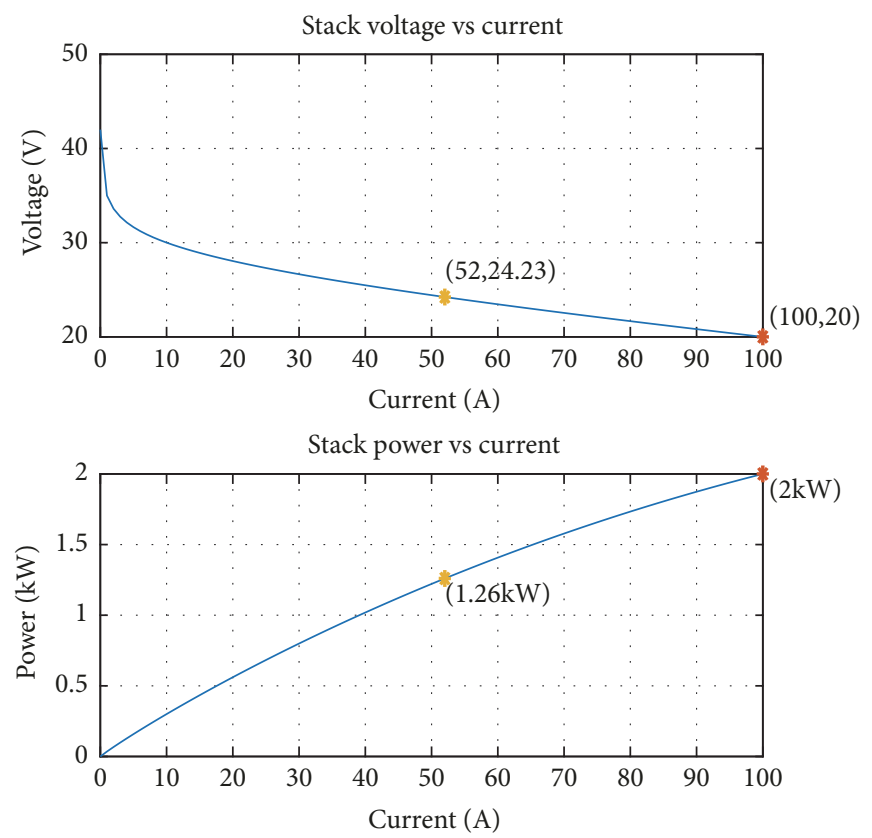

FIGURE 11: Polarization curves, voltage versus current and power versus current from simulation results.
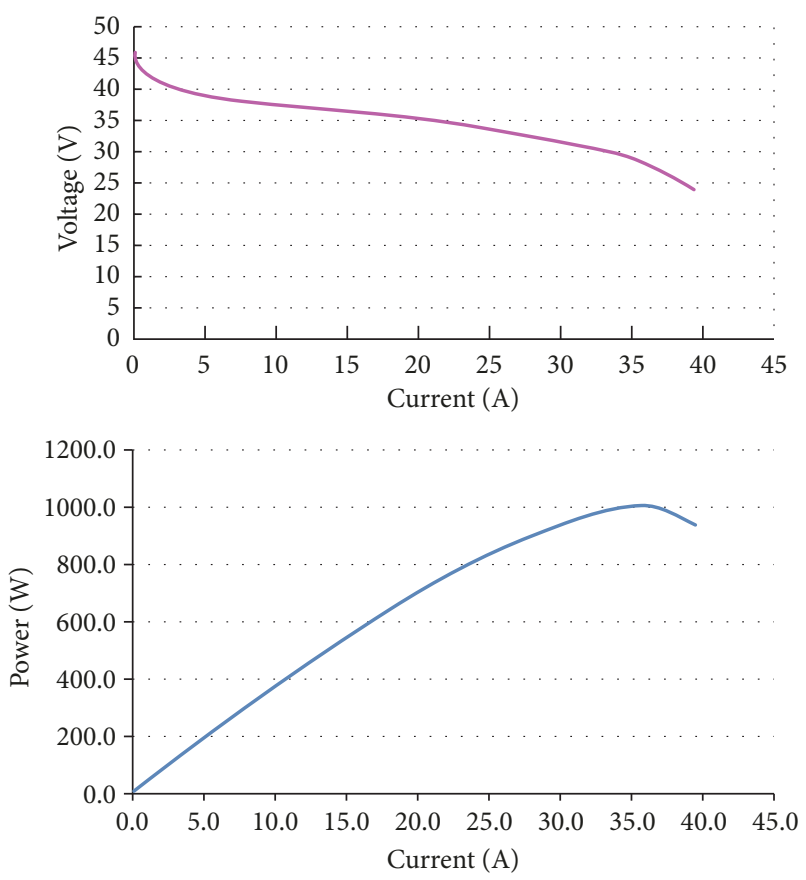

Figure 12: Polarization curves, voltage versus current and power versus current from data sheet results.

the fuel cell, a diode is used [21]. Polarization curves (V-I and P-I) from the simulation and data sheet are presented in Figures 11 and 12, respectively. The results from both MALAB/Simulink and the manufacturer's data sheet align well. The performance characteristics data of the stack are given for baseline operating conditions and defined at sea level and room ambient temperature. More information about the fuel cell is attached in the Appendix.

3.2. Lithium-Ion Battery and Converter. MATLAB/Simulink already has a built-in dynamic model for a Li-ion battery that depends on a modified Shepherd curve-fitting model. The voltage polarization term was added to the battery discharge voltage expression to ensure the representation of the battery SOC effect on the battery performance. For the simulation stability, the filtered battery current is implemented instead of the actual battery current for the polarization resistance. The model uses two equations for discharging and charging as follows [15]:

Discharge Model When $i^{*}$ Is Greater Than Zero

$$
\begin{aligned}
V_{\text {batt }}= & E_{0}-K \frac{Q}{Q-i t} \cdot i^{*}-K \cdot \frac{Q}{Q-i t} \cdot i t+A \\
& \cdot \exp (-B \cdot i t)-R_{b} . I
\end{aligned}
$$

Charge Model When $i^{*}$ Is Less Than Zero

$$
\begin{aligned}
V_{b a t t}= & E_{0}-K \cdot \frac{Q}{i t+0.1 Q} \cdot i^{*}-K \cdot \frac{Q}{Q-i t} \cdot i t+A \\
& \cdot \exp (-B \cdot i t)
\end{aligned}
$$

Figure 13 illustrates the dynamic model for a Li-ion battery in MATLAB/Simulink. Table 4 also shows the battery model input parameters.

The simulation discharge curves for the Li-ion battery system (i.e., $48 \mathrm{~V}$ and $34 \mathrm{Ah}$ ) are shown in Figure 14.

The average mode boost converter is used in this simulation, and its parameters are illustrated in Table 5. For the $\mathrm{DC} / \mathrm{DC}$ converter parameters, some equations have been 


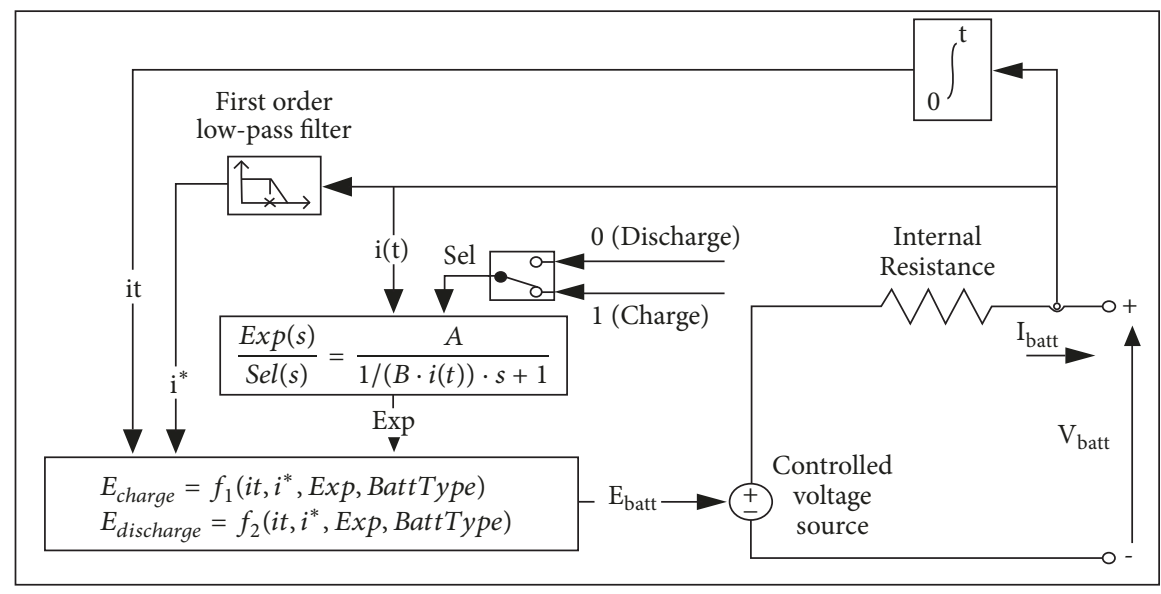

FIGURE 13: Dynamic model for Li-ion battery [15].

Nominal Current Discharge Characteristic at 0.43478C (14.7826A)

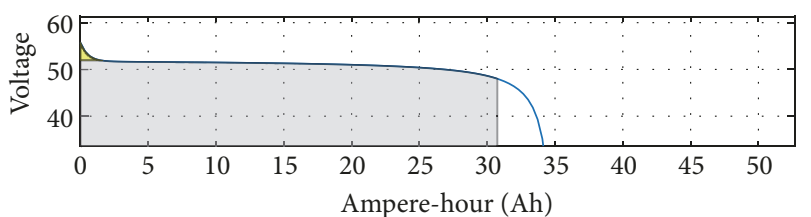

- Discharge curve

$\square$ Nominal area

$\square$ Exponential area

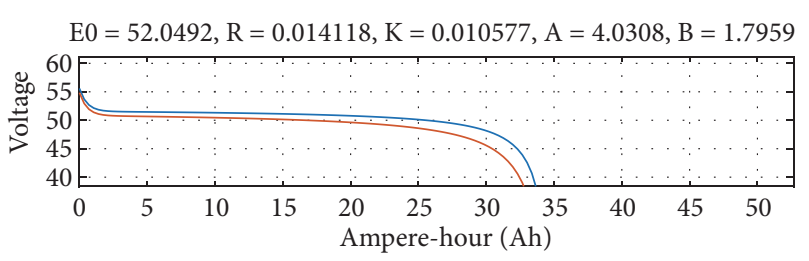

$20 \mathrm{~A}$

$-50 \mathrm{~A}$

FIGURE 14: Simulation discharge curves for the Li-ion battery.

implemented to calculate the values for duty cycle (D), inductance (L), and capacitance (C) [22]:

$$
\begin{aligned}
& D=1-\frac{\left(V_{\text {in_min }} * n\right)}{V_{\text {out }}} \\
& L=\frac{\left(V_{\text {in }} *\left(V_{\text {out }}-V_{\text {in }}\right)\right)}{\left(I_{\text {in }} * f_{s} * V_{\text {out }}\right)}, \text { and } \\
& C=\frac{I * D}{f_{s} * d v}
\end{aligned}
$$

where $\mathrm{D}$ is the duty cycle, which equals the fraction of time where the switch is connected in position 1 , and hence $0 \leq \mathrm{D} \leq$ 1. $\mathrm{V}_{\text {in_min }}$ is the minimum input voltage, and $\mathrm{n}$ is the efficiency set to $90 \%$. The variable $\mathrm{F}_{\mathrm{s}}$ is the switching frequency, $\mathrm{V}_{\text {out }}$ is the output voltage, $\mathrm{I}_{\text {in }}$ is the input current, and dv is the output voltage ripple [23].
TABLE 4: Battery model input parameters.

\begin{tabular}{lc}
\hline Battery Model Input Parameters & Value \\
\hline Nominal Voltage & $48(\mathrm{~V})$ \\
Rated capacity & $34(\mathrm{Ah})$ \\
Maximum capacity & $34(\mathrm{Ah})$ \\
Fully charged Voltage & $55.87(\mathrm{~V})$ \\
Nominal Discharge Current & $14.78(\mathrm{~A})$ \\
Internal Resistance & $0.014(\mathrm{Ohm})$ \\
Capacity at Nominal Voltage & $30.74(\mathrm{Ah})$ \\
\hline
\end{tabular}

TABLE 5: Boost converter parameters.

\begin{tabular}{lcc}
\hline Parameters & Value & Units \\
\hline Switching freq. F & 20 & $\mathrm{kHz}$ \\
Inductance L & 500 & $\mu \mathrm{H}$ \\
Capacitance C & 7500 & $\mu \mathrm{F}$ \\
Load Resistor R & 0.2 & $\Omega$ \\
\hline
\end{tabular}

3.3. Permanent Magnetic DC Motor (PMDC). The dynamic model for any PMDC motor can be represented by the following equations [24]:

$$
\begin{aligned}
\frac{d I_{a}}{d t} & =\frac{1}{L_{a a}} *\left(V_{t}-I_{a} * R_{a}-K_{m} * \omega_{m}\right) \\
\frac{d \omega_{m}}{d t} & =\frac{1}{J} *\left(T_{e}-T_{L}-B_{m} * \omega_{m}\right)
\end{aligned}
$$

Table 6 shows the parameters for the DC motor implemented in MATLAB/Simulink. Most of these values were collected from the DC motor datasheet. Figure 15 shows the system dynamic flow rate regulators and flow rate selector. The blue and green blocks represent the hydrogen and oxygen tanks, respectively. They both enter the fuel cell stack in order to get power. The fuel cell is connected to the boost converter to increase the voltage from $24 \mathrm{~V}$ to $48 \mathrm{~V}$, which is required by the battery and the load (i.e., DC motor). The yellow block illustrates the MUN Explorer's motor. 


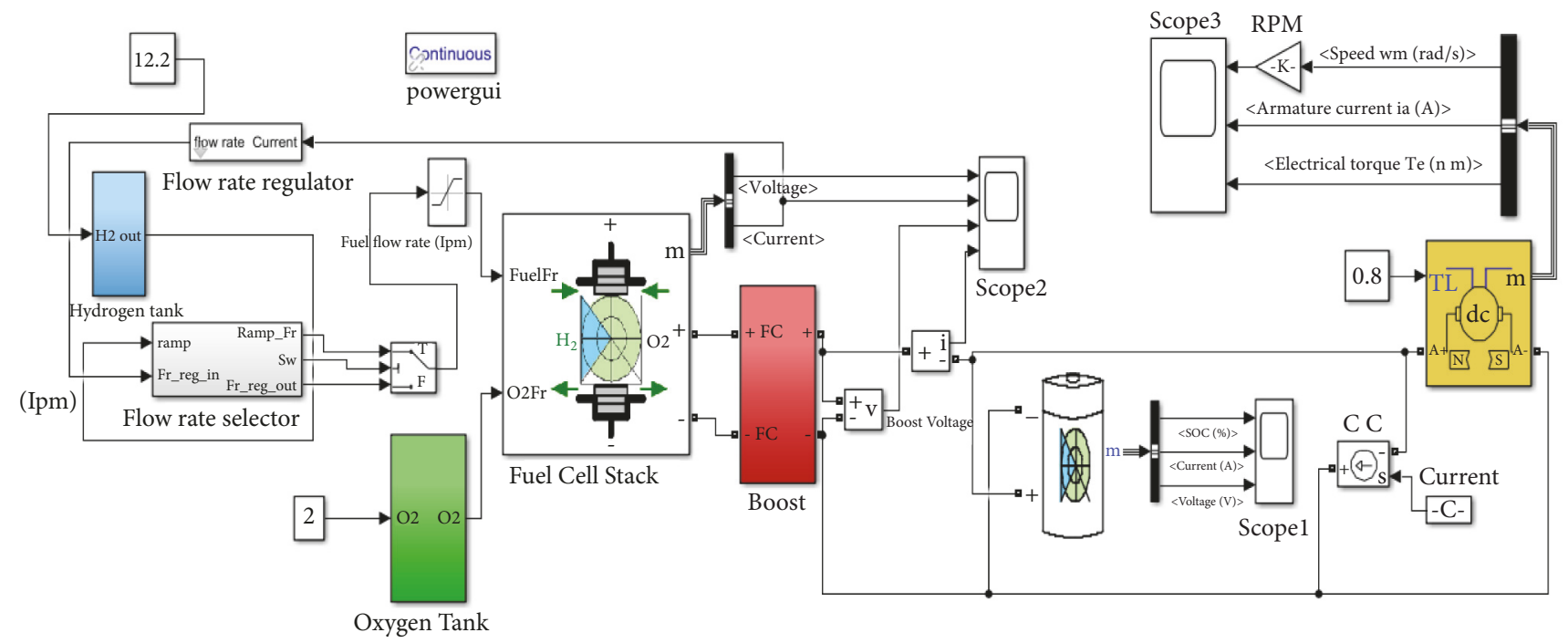

FIgURE 15: Dynamic model in MATLAB/Simulink Software.

TABLE 6: PMDC motor parameters.

\begin{tabular}{lcc}
\hline Parameters & Value & Unit \\
\hline Armature V & 48 & $\mathrm{~V}$ \\
Armature Ra & 0.3 & $\mathrm{Ohms}$ \\
Armature La & 0.00208 & $\mathrm{H}$ \\
Torque constant & 0.099 & $\mathrm{~N} . \mathrm{m} / \mathrm{A}$ \\
Total Inertia J & $15 \mathrm{e}-5$ & $\mathrm{Kg} \cdot \mathrm{m}^{\wedge} 2$ \\
\hline
\end{tabular}

\section{Results and Discussion}

The simulation in HOMER software was done to get the sizing results for the integrated power system. The system component inputs were specified based on the cost and sizes to consider for each block. From Figure 2, the components of the PV wind turbine and electrolyzer can not be applied to the MUN Explorer due to the lack of space available, and they will be used to generate the required oxygen and hydrogen gases to run the fuel cell. From Figure 4, the assumptions of the wind and PV energy are determined based on the wind speed directions and solar radiations of St. John's, Newfoundland, which is where this technology will be integrated. The oxygen/hydrogen tanks and fuel cell along with the batteries are planned to be installed in the MUN Explorer. The gray line also shows the most optimal results. From my point of view, the results have shown the lowest operating cost and reduce the number of batteries from 11 to 8 . The advantage of minimizing the number of batteries is that it leaves more space for installing the fuel cell and the tanks. The hydrogen stored in the cylinders can be generated from renewable energy sources as a step prior to running the MUN Explorer. Figures 16 and 17 show the pressure inside the oxygen and hydrogen tanks, respectively.

A 6-kg hydrogen tank needs to be installed inside the explorer to run the fuel cell. In terms of the oxygen tank, it

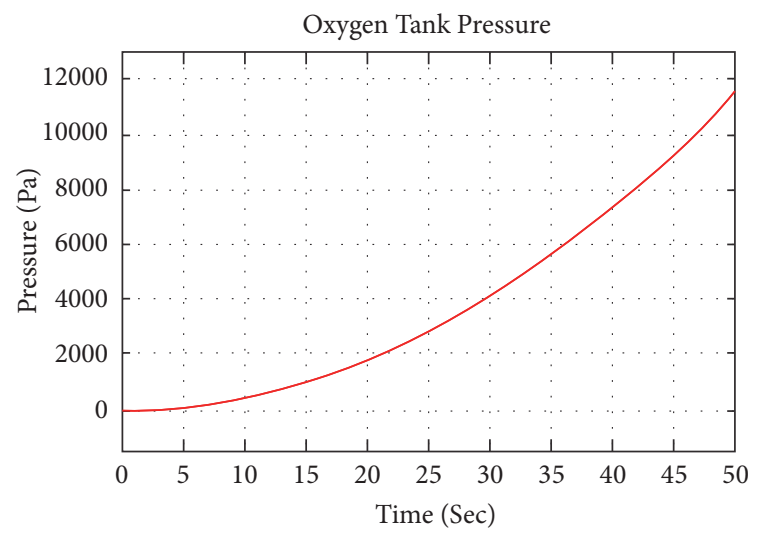

Figure 16: The pressure of compressed oxygen tank.

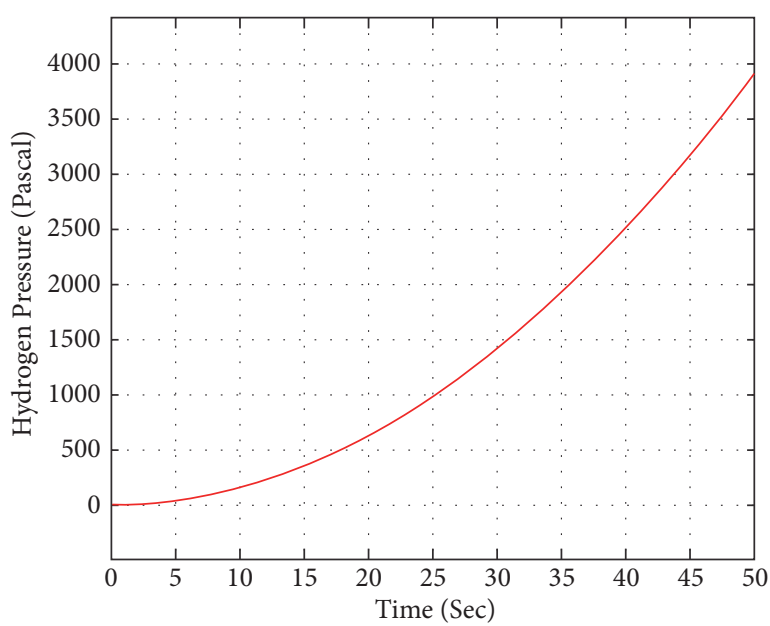

FIGURE 17: The pressure of compressed hydrogen tank. 

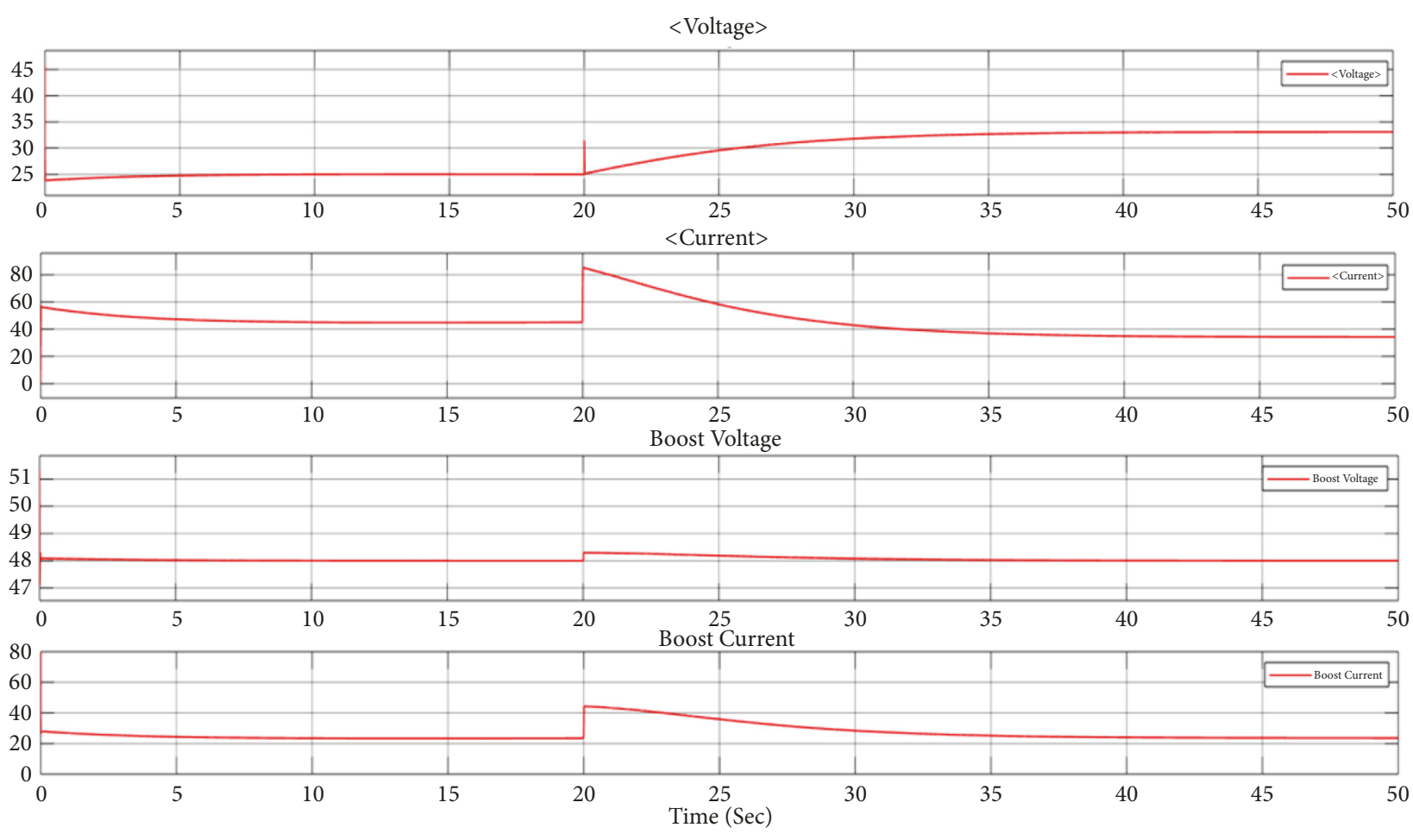

Figure 18: The voltage and current of fuel cell and Boost converter.

TABLE 7: PI coefficients for boost converter.

\begin{tabular}{lc}
\hline Parameter & Value \\
\hline $\mathrm{K}_{\mathrm{p}}$ & 0.0005 \\
$\mathrm{~K}_{\mathrm{i}}$ & 0.15 \\
\hline
\end{tabular}

can be installed as the hydrogen tank specifications which was suggested in the literature. The oxygen tank size is considered the same as the one in [20]. The fuel cell has $1 \mathrm{~kW}$ of power to feed the DC motor and to charge the battery once it gets enough power. Firstly, the fuel cell is connected to the boost converter, which takes $24 \mathrm{~V}$ to $48 \mathrm{~V}$, which is required by the battery and DC motor, as shown in Figure 18. The assumptions of the fuel cell model are as follows: all gases are ideal, pressure drops across flow channels are negligible, and cell voltage drops are due to reaction kinetics and charge transport [14]. A PI controller is used to control the output voltage from the boost converter to maintain the $48 \mathrm{~V}$ for the battery and DC motor. The PI coefficients are shown in Table 7.

From Figure 18, we can clearly see that after 20 seconds, the fuel cell started to run to power the DC motor. This starting time is recommended by the fuel cell manufacturer and controlled by the fuel cell regulator. The battery is set to $50 \%$ state of charge (SOC) to prevent any damage to the battery and does not allow it to charge to $100 \%$. The nominal discharge current is 14.78 A. Figure 19 shows the fuel cell power profile in HOMER through the year.

There are 11 batteries connected in series to power the AUV for 10 hours. Figure 20 illustrates the battery behavior in terms of SOC, current, and voltage from the Simulink model, whereas Figure 21 shows the state of charge profile from HOMER sizing during the year. Figure 22 illustrates the PMDC motor, which runs at a constant speed. This constant speed is maintained by the boost converter to run the AUV at a constant speed. After that, the DC motor runs at its highest efficiency. The armature current is 16 , which is very close to the manufacturer data sheet value. Figure 23 demonstrates the DC motor power profile in HOMER software.

The monthly average electric power production from the system (i.e., PV, wind, and fuel cell) is shown in Figure 24. The solar and wind energy are used to produce oxygen and hydrogen gas by powering an electrolyzer as well as recharging the batteries. The fuel cell power production is low compared to the PV and wind power due to the integration of the fuel cell into the battery system, which has a large amount of energy to power the DC motor. Table 8 shows the results for energy density and specific energy for the storage and total system with the fuel cell. The calculations are based on the total system's mass and weight, which can be illustrated as summations of the storage and fuel cell systems. The estimated results are shown due to the main balance of plant components that were integrated into commercial fuel cells.

Table 8 shows a significant improvement in terms of specific energy and energy density, especially for liquid oxygen and hydrogen storage options. In [16], Li-ion batteries have specific energies from $0.165 \mathrm{kWh} / \mathrm{kg}$ to $0.207 \mathrm{kWh} / \mathrm{kg}$ and energy densities from $0.329 \mathrm{kWh} / \mathrm{L}$ to $0.490 \mathrm{kWh} / \mathrm{L}$ [16]. The largest improvements are in the specific energy of the fuel cell total systems when compared with the lithium-ion batteries. To show the buoyancy effect on the system, the 
TABLE 8: SE and ED for storage and total fuel cell.

\begin{tabular}{lcccc}
\hline & \multicolumn{2}{c}{ Storage System } & Total system \\
& $\mathrm{SE}(\mathrm{kWh} / \mathrm{kg})$ & $\mathrm{ED}(\mathrm{kWh} / \mathrm{L})$ & $\mathrm{SE}(\mathrm{kWh} / \mathrm{kg})$ & 1.024 \\
$\mathrm{~L}_{\mathrm{O} 2} / \mathrm{L}_{\mathrm{H} 2}$ & 1.233 & 1.130 & 0.701 & 0.846 \\
$\mathrm{C}_{\mathrm{O} 2} / \mathrm{C}_{\mathrm{H} 2}$ & 0.792 & 0.379 & $\mathrm{kWh} / \mathrm{L})$ \\
\hline
\end{tabular}

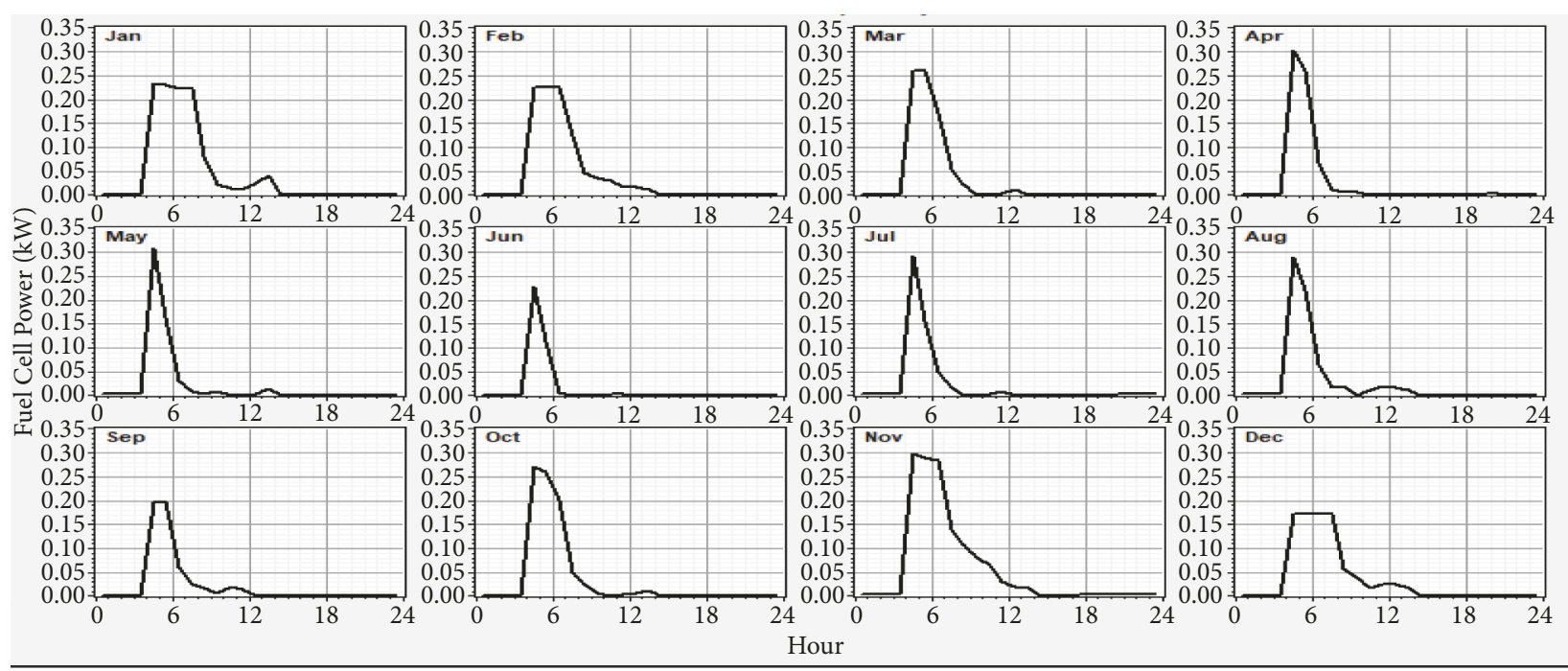

FIgURE 19: The fuel cell power profile.
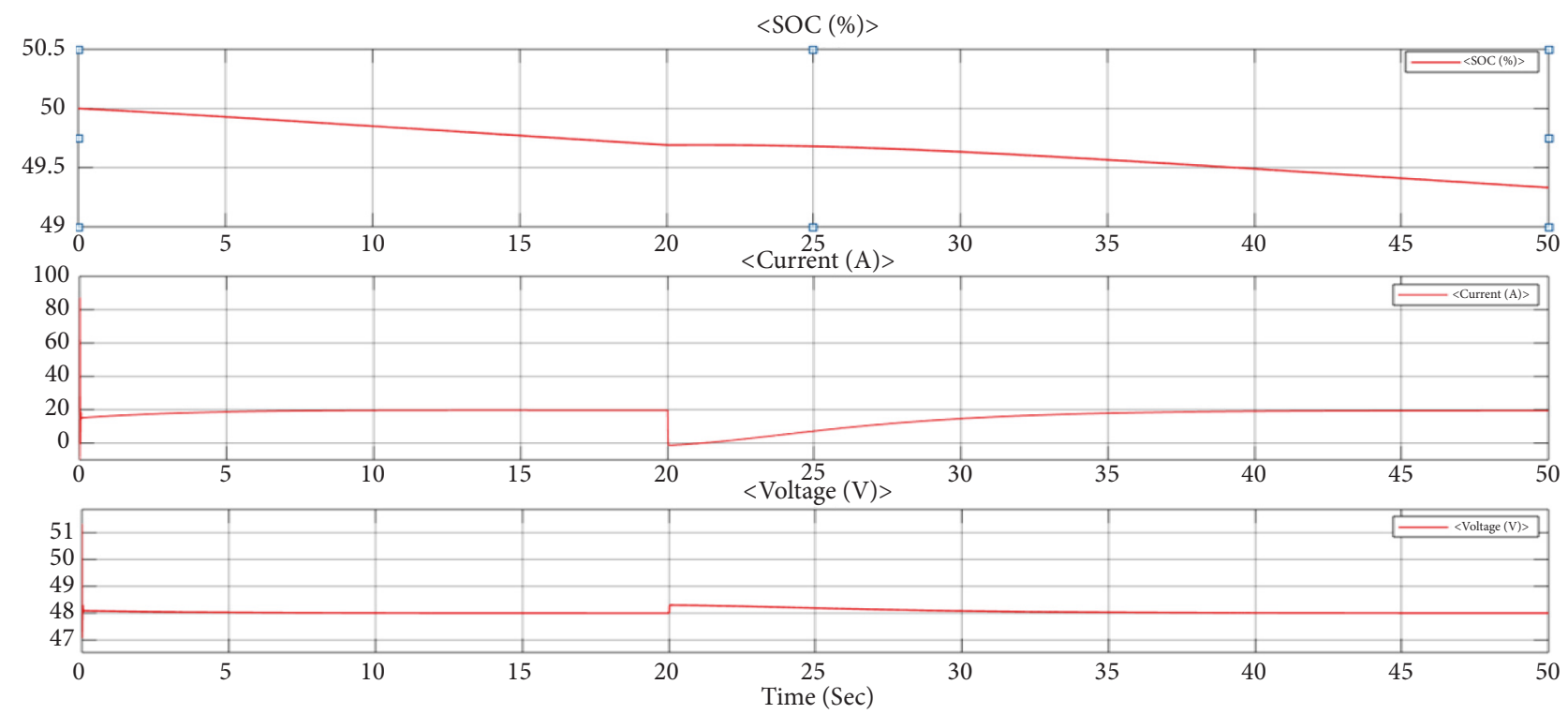

FIGURE 20: The battery characteristic SOC, current, and voltage.

density can be defined as energy density divided by specific energy [17]:

$$
D=\frac{m}{V}=\frac{E D}{S E}
$$

Figure 25 shows the relationship between ED and SE; the plotting of ED as functions of SE on the $\mathrm{X}$ and $\mathrm{Y}$ axes is the slope (i.e., $\mathrm{X}$ and $\mathrm{Y}$ intercept at any point) which is equivalent density at any point. The seawater density (1.03 $\mathrm{kg} / \mathrm{L}$ ) is shown by the dotted line. However, if there is any point above the line, it indicates negative buoyancy or being denser than seawater. Any point below the line indicates positive buoyancy or being less dense than seawater. For any given fuel cell power system design that does not require buoyancy as shown in Figure 25, some ballast or float material must be added to meet the buoyancy requirement [17]. 

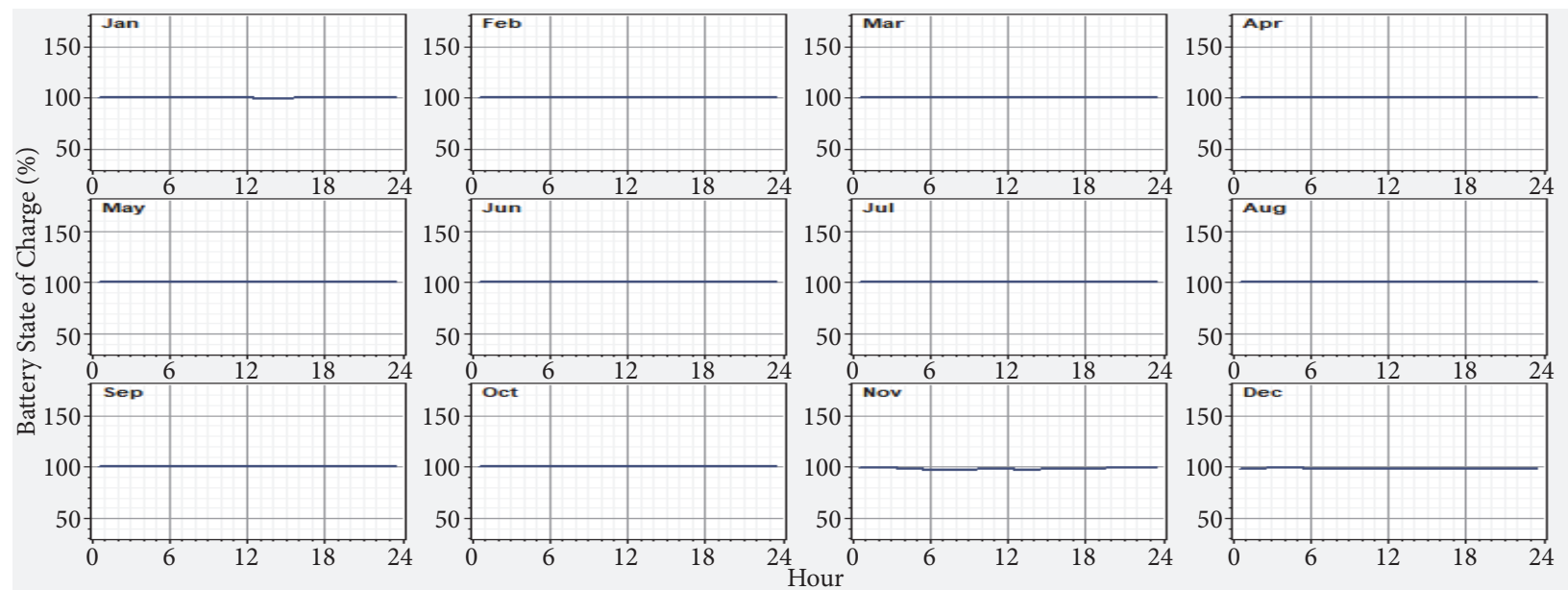

FIGURE 21: The battery power profile.
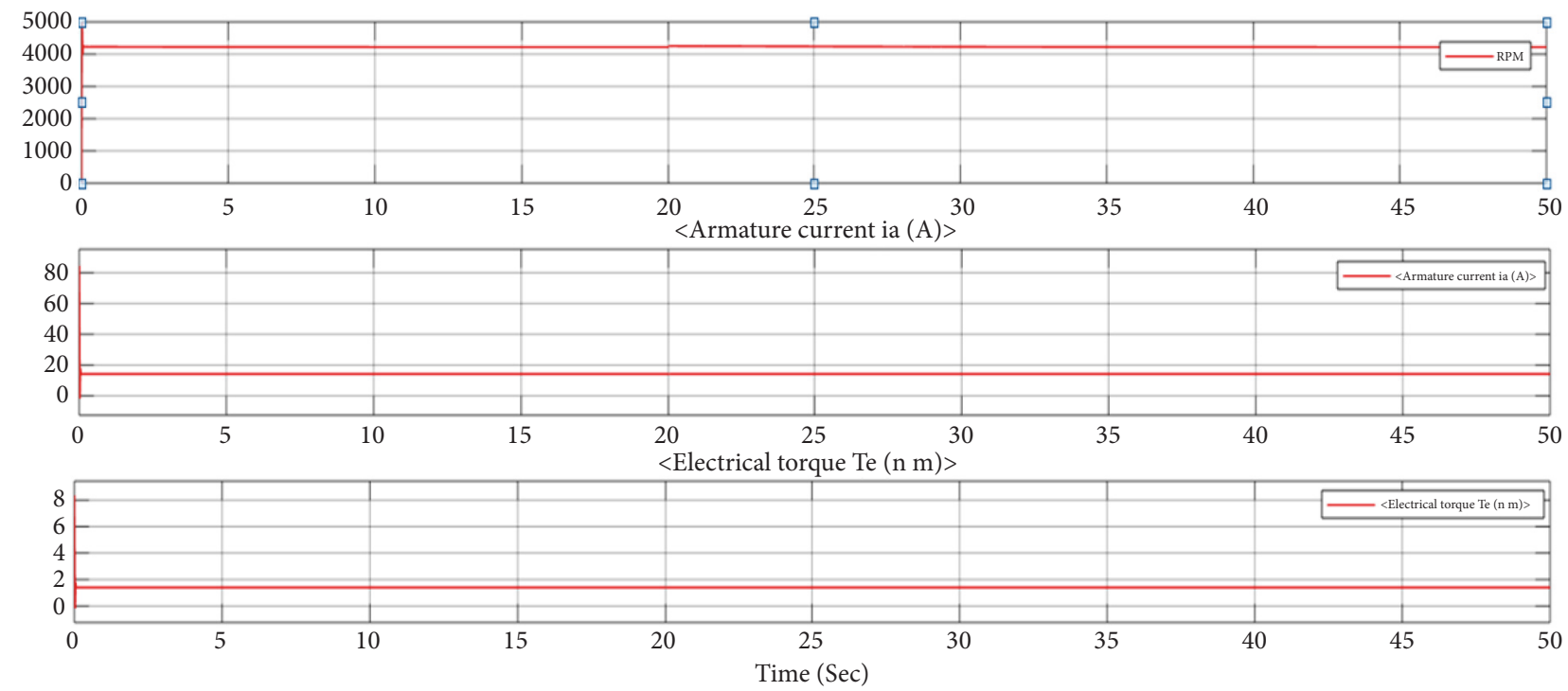

FIGURE 22: PMDC motor characteristics.

The power system's capacity is increased by integrating the fuel cell power system into the MUN Explorer according to the following calculations.

$$
\begin{aligned}
& \text { Available Energy }=\text { Power } * \text { time } \\
& \qquad \text { Watt-hour }=\text { Battery Volt } * \text { Ah }
\end{aligned}
$$

The energy capacity is increased by integrating the fuel cell into the system and the number of batteries is reduced by applying (20) and (21). More details are attached in the Appendix.

\section{Conclusions}

The sizing and modeling of the MUN Explorer's power system were studied and simulated in this paper. The oxygen and hydrogen tanks were successfully studied in terms of specific energy and energy density. They were also implemented in MATLAB/Simulink as compressed gas storage. The results showed that a fuel cell with hydrogen and oxygen storage options has a higher energy density than batteries alone. The system sizing by HOMER was studied and implemented. The power profiles from HOMER software were illustrated for the fuel cell and DC motor. A 1-kW fuel cell and $8 \mathrm{Li}$-ion batteries can increase the power system capacity to $68 \mathrm{kWh}$. Installing these options will greatly increase the hours of operation and will help the buoyancy force. The system components are simulated in MATLAB/Simulink.

Future work that builds on this paper should improve the dynamic model in MATLAB/Simulink by including some controllers in the system. The existing power system for the MUN Explorer should be built and compared with this system (i.e., fuel cell with batteries). 

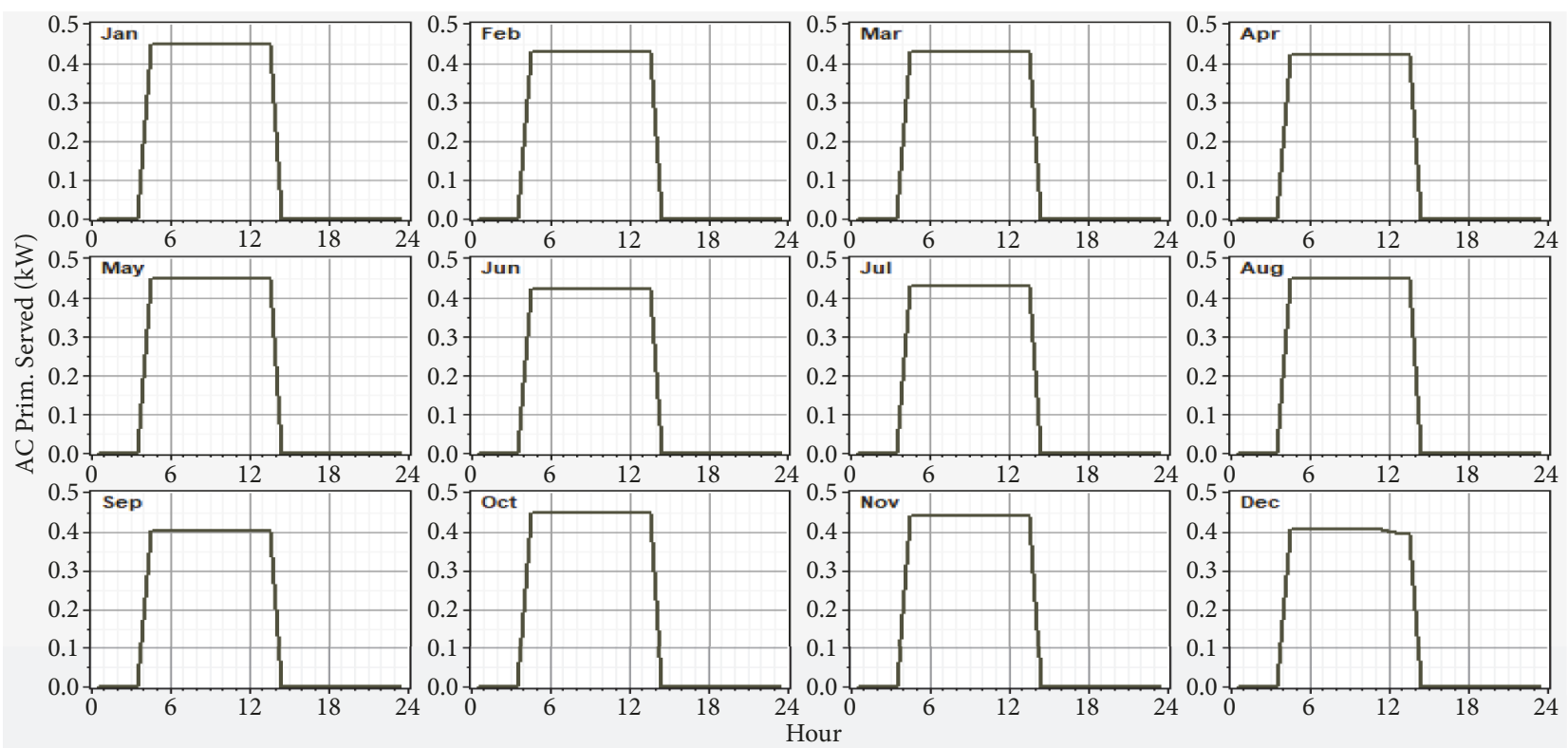

Figure 23: The DC motor power profile.

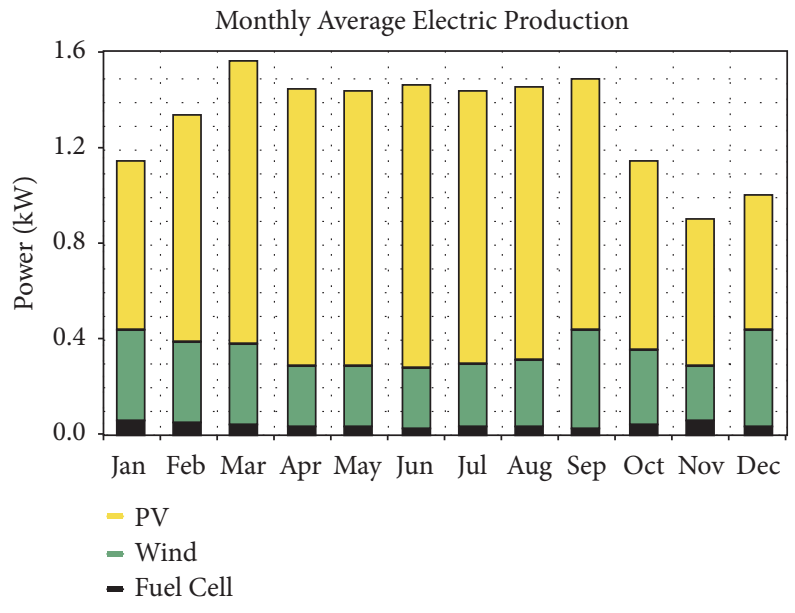

FIGURE 24: Monthly average electric production.

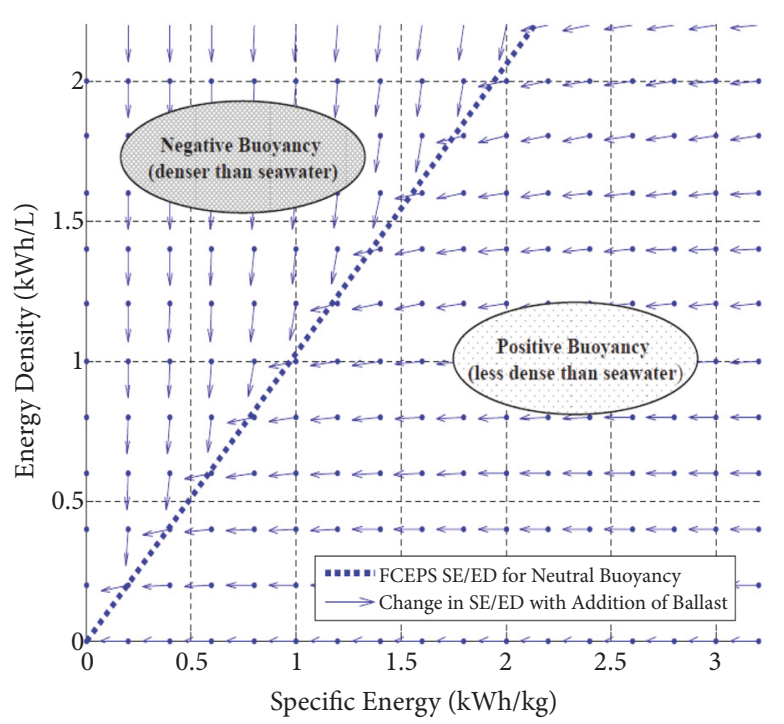

FIgURE 25: Buoyancy in terms of SE and ED [17]. 


\section{Appendix}

$\begin{array}{cc}\text { Components } & \text { Cost } \\ \text { Fuel cell (500/1k) W } & \$ 3084 / \$ 4284 \\ \text { Electrolyzer } & \$ 1509 \\ \text { Hydrogen Tank } & \$ 915 \\ \text { Battery } & \$ 840 \\ \text { Wind turbine } & \$ 800 \\ \text { PV panel } & \$ 3600 \\ \text { DC Motor } & \$ 60\end{array}$

Specifications

\begin{tabular}{ll}
\hline Characteristics & Specifications \\
\hline Length & $5.3 \mathrm{~m}$ \\
\hline Diameter & $0.69 \mathrm{~m}$ \\
\hline Dry Weight & $830 \mathrm{~kg}$ \\
\hline Energy & $17.6 \mathrm{kWh}$ \\
\hline Maximum Depth & $3000 \mathrm{~m}$ with $10 \%$ safety factor \\
\hline Typical Crusing Speed & $1.5 \mathrm{~m} / \mathrm{s}$ \\
\hline Speed Range & $0.5 \mathrm{~m} / \mathrm{s}$ to $2.5 \mathrm{~m} / \mathrm{s}$ \\
\hline Power Source and Capacity & $\begin{array}{l}11 \times 1.6 \mathrm{kWh} \text { E-One Moli Energy Li-lon Cobalt rechargeable battery } \\
\text { modules }\end{array}$ \\
\hline Computer & $\begin{array}{l}\text { Rack mount cPCl system for vehicle control and payload control } \\
\text { computer }\end{array}$ \\
\hline Hydroplanes & $\begin{array}{l}4 \mathrm{NACA} \text { 0026 stern planes } \\
2 \mathrm{NACA} 0026 \text { fore planes } \\
\text { iXsea PHINS III }\end{array}$ \\
\hline Navigation INU Type
\end{tabular}

https://www.mun.ca/engineering/research/facilities/ centres/oerc/facilities/merlin/explorerauv.php

\section{Technical Data}

E206:

Item name: ........................ Electrolyser H2/0265

Item no: ................................................... E206

HXWXD: .................... $250 \times 250 \times 120 \mathrm{~mm}$

Weight: …….......................................950 g

Number of cells: ................................................... 2

Electrode dimensions: ....................... $40 \times 40 \mathrm{~mm}$

Operating medium: .... distilled water, $0<2 \mu \mathrm{S} / \mathrm{cm}$

Fill volume H2O, H2-side: ............... approx. $90 \mathrm{ml}$

Fill volume H20, 02-side: ............. approx. $130 \mathrm{ml}$

Permissible operating voltage: ............ 0 - 4.0 VDC

Permissible operating current: ............... $0-4.4 \mathrm{~A}$

Rated power consumption: .............. approx. $16 \mathrm{~W}$

Gas production H2 at rated power output: ... approx.

$65 \mathrm{~cm}^{3} / \mathrm{min}$

Gas production 02 at rated power output: ... approx.

$32.5 \mathrm{~cm}^{3} / \mathrm{min}$
E207:

Item name: ...................... Electrolyser H2/02 230

Item no: ................................................ 2207

HxWx D: ........................ $250 \times 330 \times 200 \mathrm{~mm}$

Weight: ...................................... $1850 \mathrm{~g}$

Number of cells: ..........................................7

Electrode dimensions: ..................... $40 \times 40 \mathrm{~mm}$

Operating medium: .... distilled water, $\sigma<2 \mu \mathrm{s} / \mathrm{cm}$

Fill volume H2O, H2-side: ................ approx. $90 \mathrm{ml}$

Fill volume H2O, 02-side: ............. approx. $130 \mathrm{ml}$

Permissible operating voltage: .......... $0-14.0 \mathrm{VDC}$

Permissible operating current: ............... $0-4.4 \mathrm{~A}$

Rated power consumption: ............. approx. 56W

Gas production $\mathrm{H} 2$ at rated power output: ... approx.

$230 \mathrm{~cm}^{3} / \mathrm{min}$

Gas production 02 at rated power output: ... approx.

$115 \mathrm{~cm}^{3} / \mathrm{min}$

\begin{tabular}{|c|c|}
\hline \multicolumn{2}{|l|}{ Fuel Cell Properties } \\
\hline Number of Cells & 48 \\
\hline Rated Power & $1000 \mathrm{~W}(1 \mathrm{~kW})$ \\
\hline Rated Performance & 28.8V@ @ 35A \\
\hline $\begin{array}{r}\text { Hydrogen Supply Valve } \\
\text { Voltage }\end{array}$ & $12 \mathrm{~V}$ \\
\hline Purging Valve Voltage & $12 \mathrm{~V}$ \\
\hline Blower Voltage & $12 \mathrm{~V}$ \\
\hline Reactants & Hydrogen and Air \\
\hline Ambient Temperature & $5-30 C(41-86 F)$ \\
\hline Max Stack Temperature & $65 \mathrm{C}(149 \mathrm{~F})$ \\
\hline Hydrogen Pressure & $0.45-0.55$ Bar \\
\hline Humidification & Self-humidified \\
\hline Cooling & Air (integrated cooling fan) \\
\hline Controller Weight & $400 \mathrm{~g}( \pm 30 \mathrm{~g})$ \\
\hline $\begin{array}{r}\text { Stack Weight (with Fan \& } \\
\text { Casing) }\end{array}$ & $4 \mathrm{~kg} \pm 100 \mathrm{~g}$ \\
\hline $\begin{array}{r}\text { Hydrogen Flow Rate at Max } \\
\text { Output }\end{array}$ & $13 \mathrm{~L} / \mathrm{min}$ \\
\hline Stack Size & $268 \times 219 \times 122.5 \mathrm{~mm}\left(10.5^{\prime \prime} \times 8.6^{\prime \prime} \times 4.8^{\prime \prime}\right)$ \\
\hline $\begin{array}{r}\text { Hydrogen Purity } \\
\text { Requirement }\end{array}$ & ₹ $99.995 \%$ (dry H2) \\
\hline
\end{tabular}

https://www.fuelcellstore.com/fuel-cell-stacks/high-powerfuel-cell-stacks/horizon-1000watt-fuel-cell-h-1000

\section{ONYX +48V Battery Module EXIDE User Manual}

2.3 Module Electrical Specification

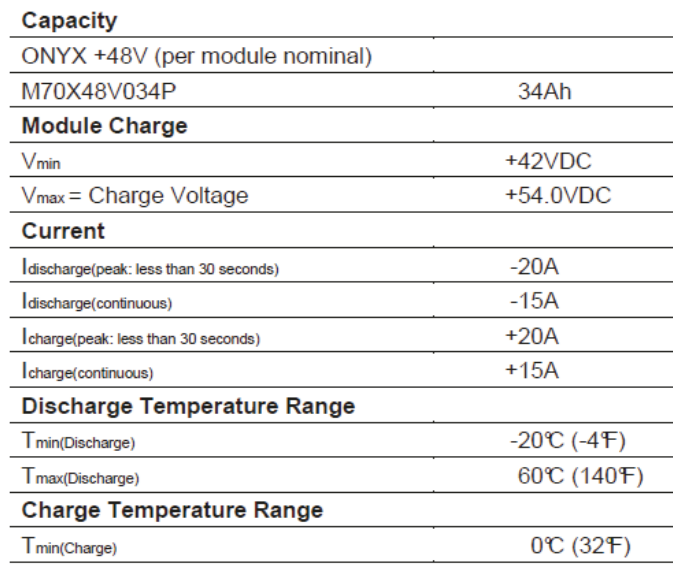

https://www.fuelcellstore.com/hydrogen-equipment/ electrolyzer-230-e107

https://www.alibaba.com/product-detail/cheapest-1000Wwind-alternator-48v-for_60158460072.html

https://www.alibaba.com/product-detail/48v-brushlessdc-motor-nema34220w_60500232517.html?spm= a2700.7724838.2017115.96.57493907yRTCES 


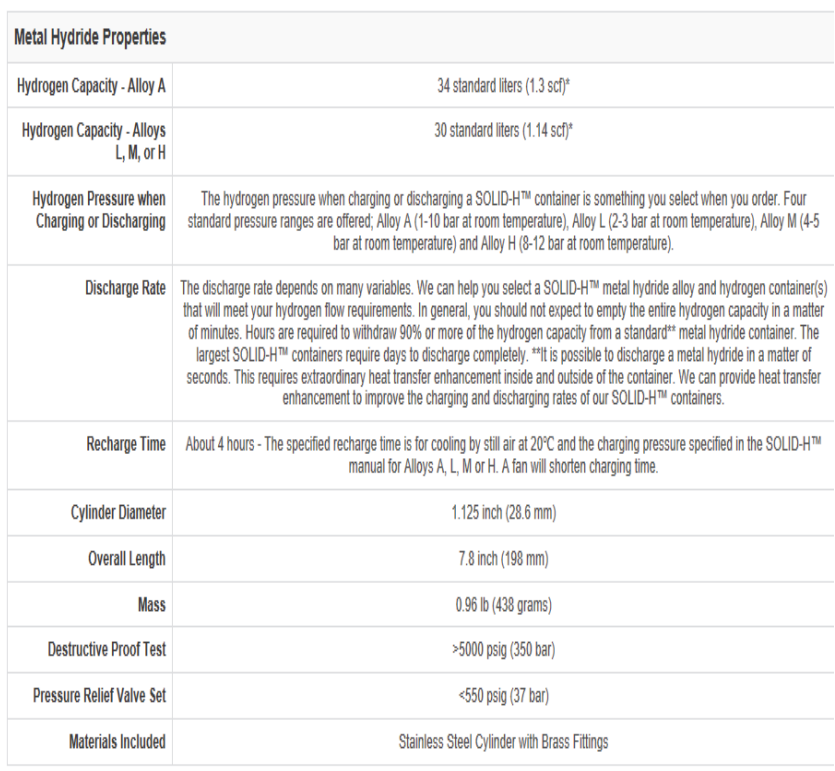

https://www.fuelcellstore.com/bl-30-metal-hydride

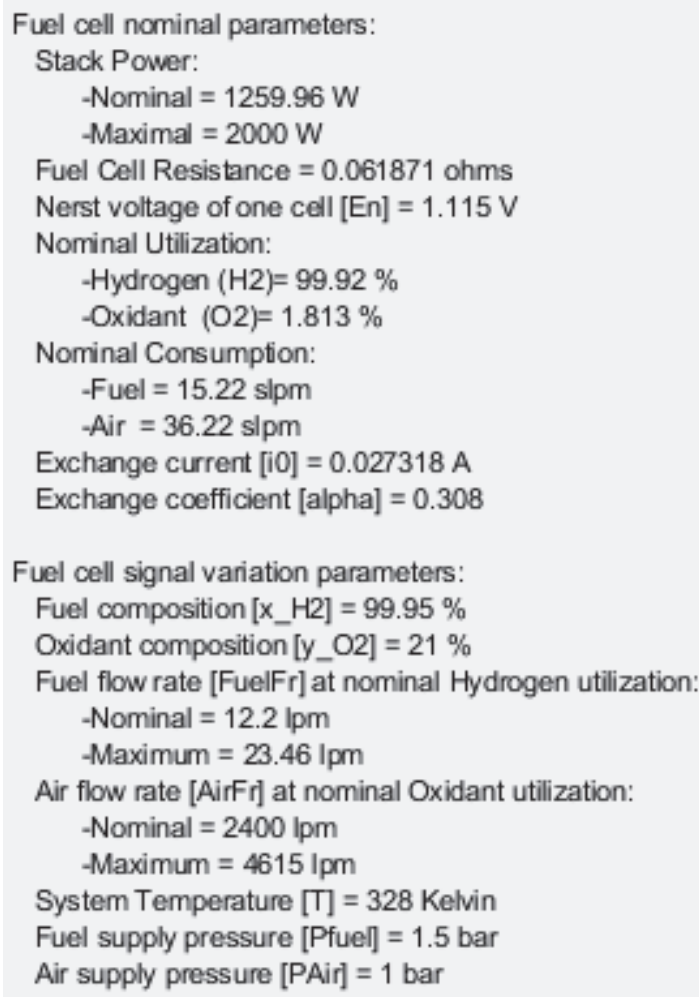

Fuel cell signal variation parameters:

Fuel composition [x_H2] $=99.95 \%$

https://www.fuelcellstore.com/hydrogen-equipment/ hydrogen-storage/bl-20-metal-hydride

https://www.fuelcellstore.com/bl-60-metal-hydride

For the selection of the three hydrogen tanks, the cost of each one has entered HOMER Software inputs based on their sizes $(\mathrm{kg})$ as listed in the table below.

Costs
\begin{tabular}{r|r|r|r|} 
Size $[\mathrm{kg})$ & Capital (\$) & Replacement (\$) & O\&M (\$/yr] \\
\hline 0.307 & 2685 & 895 & 0 \\
\hline 0.400 & 2745 & 915 & 0 \\
\hline 0.636 & 3963 & 1321 & 0 \\
\hline
\end{tabular}

And the capacity and pressure are listed below:

For $0.307 \mathrm{Kg}$

Hydrogen capacity of 20-21 standard liters (0.76-0.80 scf)

Hydrogen pressure when charging or discharging is 1-12 bar at room temperature

For $0.400 \mathrm{Kg}$

Hydrogen capacity of 30-34 standard liters (1.14-1.3 scf)

Hydrogen pressure when charging or discharging is 1-12 bar at room temperature

For $0.636 \mathrm{Kg}$

Hydrogen capacity of 60-69 standard liters (2.28-2.64 scf)

Hydrogen pressure when charging or discharging is 1-12 bar at room temperature

\section{Nomenclature}

AUV: Autonomous underwater vehicle

DC: Direct current

$\mathrm{Pb}$ : Pressure of the tank $(\mathrm{Pa})$

$\mathrm{P}_{\mathrm{bi}}$ : Initial pressure of the tank $(\mathrm{Pa})$

$\mathrm{T}_{\mathrm{b}}$ : Operating temperature $(\mathrm{K})$

$\mathrm{N}_{\mathrm{H} 2}:$ Normal hydrogen flow rate (Liter/min)

$\mathrm{V}_{\mathrm{b}}$ : Volume of the tank $\left(\mathrm{m}^{3}\right)$

T: $\quad$ Temperature (K)

Z: Compressibility factor

$\mathrm{V}_{\mathrm{m}}: \quad$ Molar volume $\left(\mathrm{m}^{3}\right)$

P: $\quad$ Pressure (pa)

ED: Energy density $(\mathrm{kWh} / \mathrm{L})$

SE: $\quad$ Specific energy $(\mathrm{kWh} / \mathrm{kg})$

SS: $\quad$ Storage system

$\mathrm{H}_{2} \mathrm{O}$ : Water

$\mathrm{H}_{2}$ : Hydrogen gas

$\mathrm{O}_{2}: \quad$ Oxygen gas

$\mathrm{P}_{\mathrm{H} 2}$ : Hydrogen pressure Anode side $(\mathrm{Pa})$

$\mathrm{R}: \quad$ Universal gas constant $(\mathrm{J} /(\mathrm{mol} . \mathrm{K})$

$\mathrm{V}_{\mathrm{a}}$ : Anode's volume (m3)

$\mathrm{H}_{2 \text { in }}$ : Hydrogen input flow rate $(\mathrm{kg} / \mathrm{sec})$

$\mathrm{H}_{\text {2out }}$ : Hydrogen output flow rate $(\mathrm{kg} / \mathrm{sec})$

$\mathrm{P}_{\mathrm{o} 2}$ : Oxygen pressure cathode side $(\mathrm{Pa})$

$\mathrm{V}_{\mathrm{c}}$ : Cathode's volume $\left(\mathrm{m}^{3}\right)$

$\mathrm{O}_{2 \text { in }}$ : Oxygen input flow rate $(\mathrm{kg} / \mathrm{sec})$

$\mathrm{O}_{2 \text { out }}$ : Oxygen output flow rate $(\mathrm{kg} / \mathrm{sec})$ 


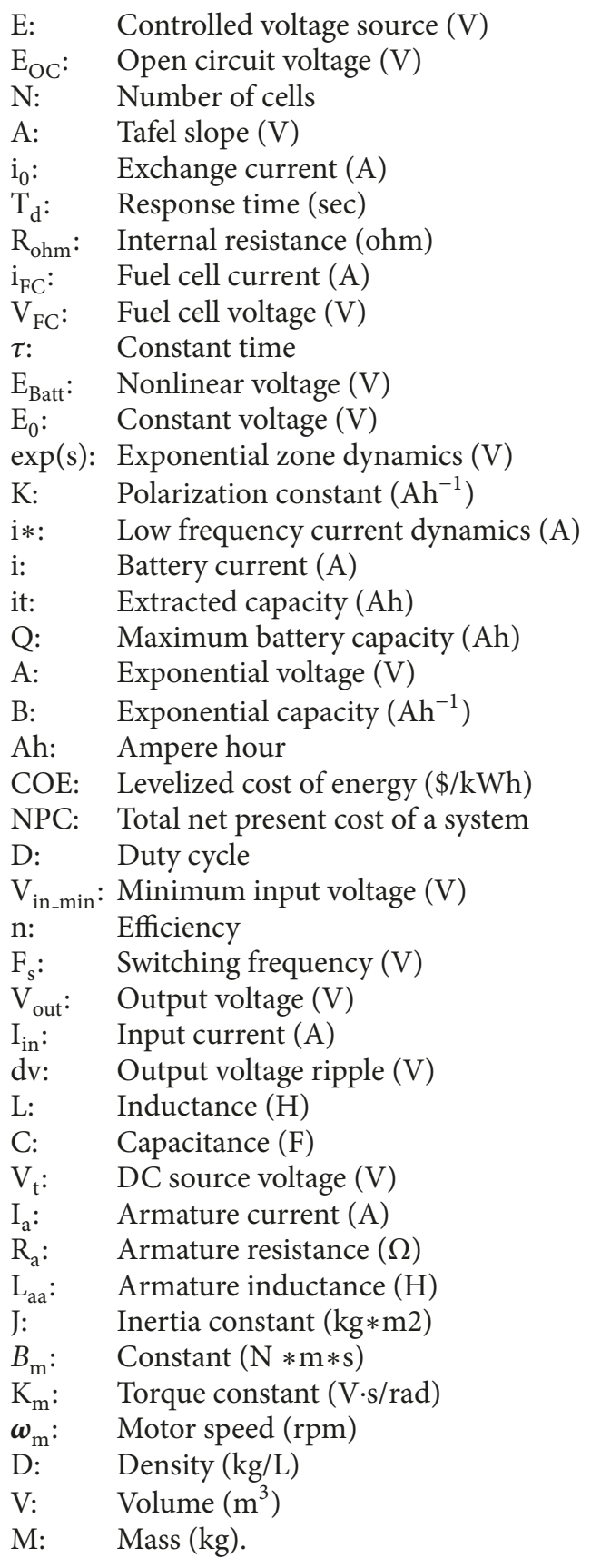

\section{Data Availability}

The data used to support the findings of this study are available from the corresponding author upon request.

\section{Conflicts of Interest}

The authors declare that they do not have any conflicts of interest in regard to this publication.

\section{Acknowledgments}

The authors would like to thank Libyan Government for financial support for this work.

\section{References}

[1] Q. Cai, D. J. Browning, D. J. Brett, and N. P. Brandon, "Hybrid fuel cell/battery power systems for underwater vehicles," in Proceedings of the 3rd SEADS STC Technical Conference, Edinburgh, 2007.

[2] B. Lee, K. Park, and H.-M. Kim, "Dynamic simulation of PEM water electrolysis and comparison with experiments," International Journal of Electrochemical Science, vol. 8, no. 1, pp. 235-248, 2013.

[3] John Speranza, Proton OnSite, and C. T. Wallingford, "The effects of hydrogen purity on GC analysis and column life," Electrolysis, 2015.

[4] A. Uluoglu, Solar- hydrogen stand-alone power system design and simulations [Ph.D. Thesis], Mechanical Engineering, 2010.

[5] K. Sopian, M. Z. Ibrahim, W. R. Wan Daud, M. Y. Othman, B. Yatim, and N. Amin, "Performance of a PV-wind hybrid system for hydrogen production," Journal of Renewable Energy, vol. 34, no. 8, pp. 1973-1978, 2009.

[6] S. N. Motapon, A. Lupien-Bedard, L. Dessaint, H. FortinBlanchette, and K. Al-Haddad, "A generic electrothermal Li-ion battery model for rapid evaluation of cell temperature temporal evolution," IEEE Transactions on Industrial Electronics, vol. 64, no. 2, pp. 998-1008, 2017.

[7] V. K. Kumaraswamy and J. E. Quaicoe, "Tracking techniques for the PEMFC in portable applications," in Proceedings of the 2016 IEEE Electrical Power and Energy Conference, EPEC 2016, Canada, October 2016.

[8] S. Curtin and J. Gangi, "Fuel cell technologies market report 2014," U.S. Department of Energy EERE, pp. 1-58, 2013.

[9] A. T-Raissi, "Current technology of fuel cell systems," in Proceedings of the 32nd Intersociet In Energy Conversion Engineering Conference, (IECEC-97), vol. 3, pp. 1953-1957, 1997.

[10] Ø. Hasvold, N. J. Størkersen, S. Forseth, and T. Lian, "Power sources for autonomous underwater vehicles," Journal of Power Sources, vol. 162, no. 2, pp. 935-942, 2006.

[11] E. Raugel, V. Rigaud, and C. Lakeman, "Sea experiment of a survey AUV powered by a fuel cell system," in Proceedings of the 2010 IEEE/OES Autonomous Underwater Vehicles, AUV 2010, USA, September 2010.

[12] M. Uzunoglu, O. C. Onar, and M. S. Alam, "Modeling, control and simulation of a PV/FC/UC based hybrid power generation system for stand-alone applications," Journal of Renewable Energy, vol. 34, no. 3, pp. 509-520, 2009.

[13] H. Gorgun, "Dynamic modelling of a proton exchange membrane (PEM) electrolyzer," International Journal of Hydrogen Energy, vol. 31, no. 1, pp. 29-38, 2006.

[14] R. Gerasimos, S. Pierluigi, W. Patrice, and L. Vincenzo, "A PEM fuel cells control approach based on differential flatness theory," Intelligent Industrial Systems 2, vol. no. 2, pp. 107-117, 2016.

[15] S. Njoya Motapon, L. Dessaint, and K. Al-Haddad, "A comparative study of energy management schemes for a fuel-cell hybrid emergency power system of more-electric aircraft," IEEE Transactions on Industrial Electronics, vol. 61, no. 3, pp. 13201334, 2014.

[16] M. Alejandro, T. Leo, and M. Herreros, "Fuel cell power systems for autonomous underwater Vehicles: state of the art," in Proceedings of the 1st International of ECE, 2014.

[17] L. Davies Kevin and M. Robert, UUV FCEPS Technology Assessment and Design Process, University of Hawaii, 2006. 
[18] A. Chakravarty, T. K. Nizami, and C. Mahanta, "Real time implementation of an adaptive backstepping control of buck converter PMDC-motor combinations," in Proceedings of the 3rd Indian Control Conference, ICC 2017, pp. 277-282, India, January 2017.

[19] K. E. Swider-Lyons, R. T. Carlin, R. L. Rosenfeld, and R. J. Nowak, "Technical issues and opportunities for fuel cell development for autonomous underwater vehicles," in Proceedings of the 2002 Workshop on Autonomous Underwater Vehicles, pp. 6164, USA, June 2002.

[20] G. Griffiths, D. Reece, P. Blackmore, M. Lain, S. Mitchell, and J. Jamieson, "Modeling Hybrid Energy Systems for Use in AUVs," Unmanned Untethered Submersible Technology, 2005.

[21] N. M. Souleman, O. Tremblay, and L.-A. Dessaint, "A generic fuel cell model for the simulation of fuel cell vehicles," in Proceedings of the 5th IEEE Vehicle Power and Propulsion Conference, VPPC '09, pp. 1722-1729, USA, September 2009.

[22] H. J. Sira-Ramirez and R. Silva-Ortigoza, Control Design Techniques in Power Electronics Devices, Springer Science \& Business Media, Berlin, Germany, 2006.

[23] R. W. Erickson, “DC-DC Power Converters," Wiley Encyclopedia of Electrical and Electronics Engineering, 2001.

[24] M. M. Shebani and T. Iqbal, "Dynamic modeling, control, and analysis of a solar water pumping system for Libya," Journal of Renewable Energy, vol. 2017, Article ID 8504283, 13 pages, 2017. 

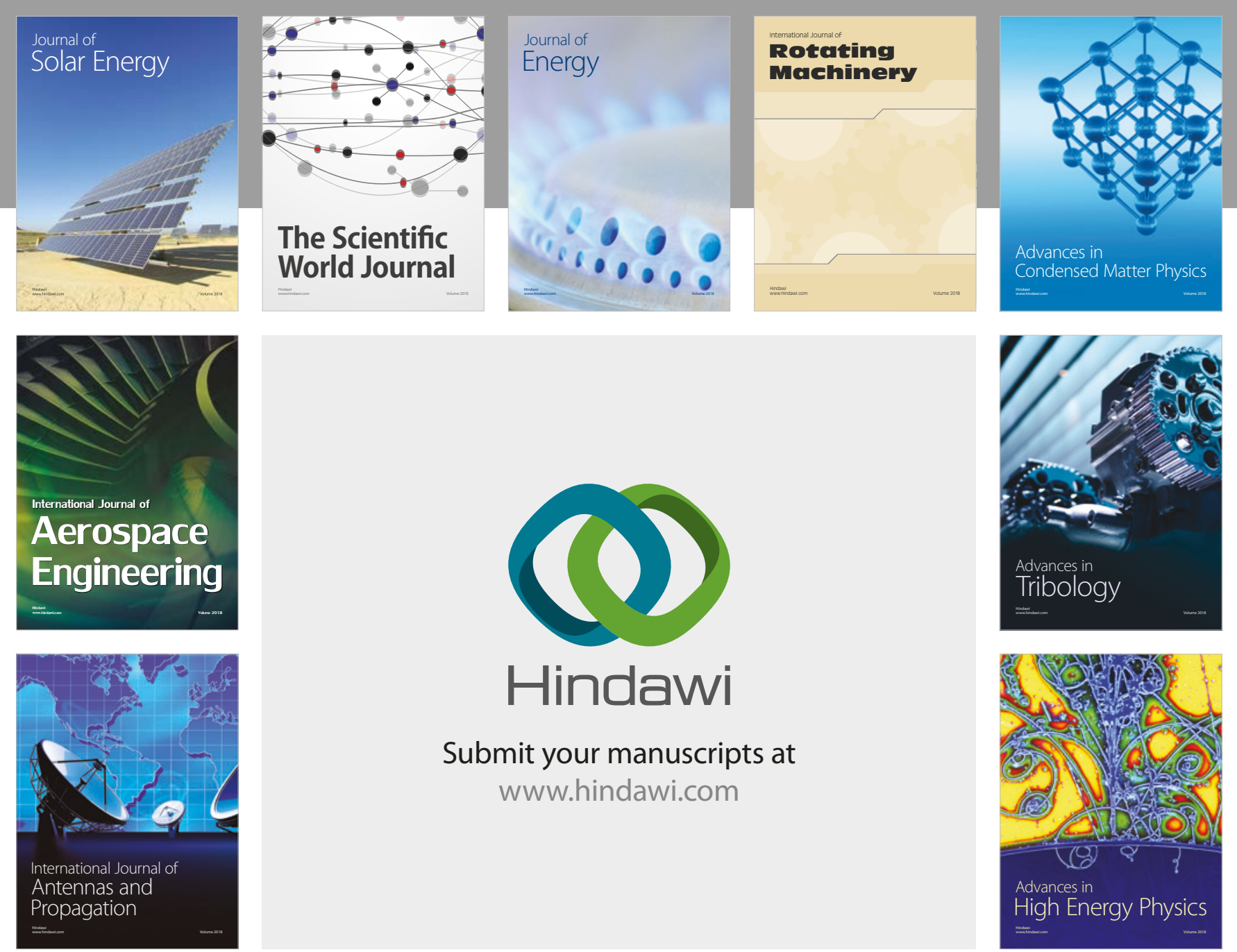

Submit your manuscripts at

www.hindawi.com
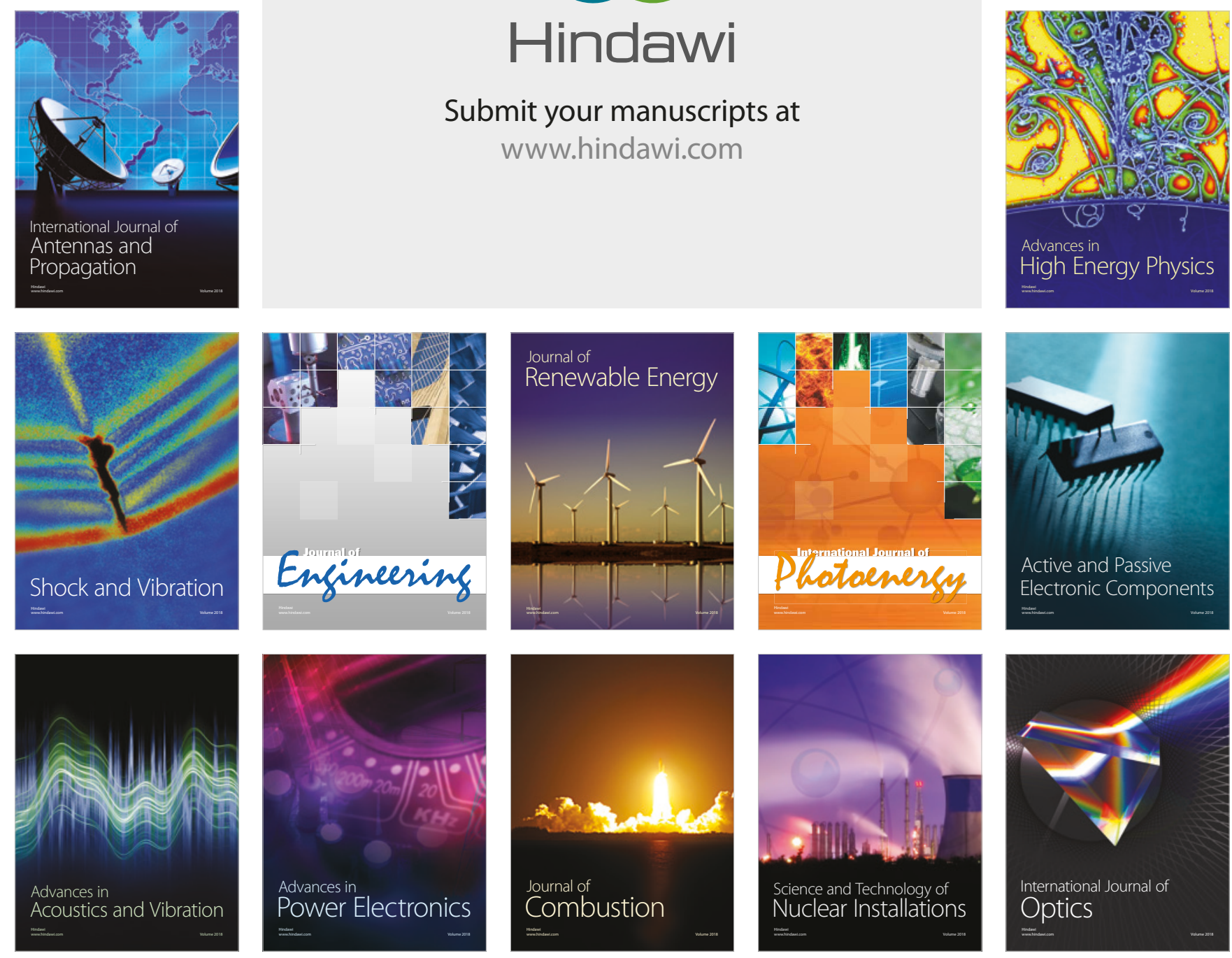